Article

\title{
Peat-Forming Environments and Evolution of Thick Coal Seam in Shengli Coalfield, China: Evidence from Geochemistry, Coal Petrology, and Palynology
}

\author{
Jian Shen ${ }^{1,2, *} \mathbb{C}^{\mathbb{D}}$, Yong Qin ${ }^{1,2}$, Jinyue Wang ${ }^{1,2}$, Yulin Shen ${ }^{1,2}$ and Geoff Wang ${ }^{3}$ \\ 1 School of Resources and Geosciences, China University of Mining and Technology, Xuzhou 221116, China; \\ yongqin@cumt.edu.cn (Y.Q.); Wjinyue2018cumt@126.com (J.W.); yulinsh@sohu.com (Y.S.) \\ 2 Key Laboratory of Coalbed Methane Resources and Reservoir Formation Process, Ministry of Education, \\ China University of Mining and Technology, Xuzhou 221008, China \\ 3 School of Chemical Engineering, The University of Queensland, Brisbane, QLD 4072, Australia; \\ gxwang@uq.edu.au \\ * Correspondence: jianshen@cumt.edu.cn; Tel.: +86-0516-8359-1000
}

Received: 3 November 2017; Accepted: 23 February 2018; Published: 26 February 2018

\begin{abstract}
Due to the importance of the wide occurrence of thick coal seams for Chinese coal resources, the origins of these seams have received considerable attention. Using the Early Cretaceous No. 5 coal seam with a thickness of $16.8 \mathrm{~m}$ in Inner Mongolia as a case study, this paper presents a systematic investigation of the coal petrology, geochemistry, and palynology of 19 coal samples to explain the origin and evolution of peat accumulation. The results indicate that the No. 5 coal seam is generally characterized by low rank (lignite), dominant huminite (average $=82.3 \%$ ), intermediate ash yield (average $=16.03 \%$ ), and sulfur content (average $=1.12 \%$ ). The proportion of spores generally increases from the bottom to the top of the coal seam, whereas the proportion of pollen decreases. The vegetation in the coal seam is dominated by gymnosperms at the bottom and by ferns at the top. The paleographic precursor peat was most likely accumulated in the lakeshore where herbaceous and bushy helophytes were dominant. The total sulfur content was positively related to the huminite content. The sulfur content was possibly derived from bacterial action with sulfur brought in via marine incursions. Three overall declining-increasing values of carbon isotopes within the No. 5 coal seam possibly indicated three general cooling trends during peat accumulation. The environment of peat accumulation included three cycles, including one drying-wetting-drying in the bottom part and two drying-upwards cycles in the upper part. These cycles of the peat-accumulation environment could likely be ascribed to climate change because of their good agreement with humidity signals from plant types at that stage.
\end{abstract}

Keywords: Shengli coalfield; thick coal seam; coal petrology; geochemistry; palynology; peatforming environment

\section{Introduction}

According to a recent evaluation of coal resources in China [1], Inner Mongolia has vast coal resources $(1630 \mathrm{Gt})$ that account for $27.6 \%$ of all Chinese coal resources. The accumulated proven coal reserves in Inner Mongolia re approximately $896 \mathrm{Gt}$, which ranks first among the regions in China. The coal in Inner Mongolia is characterized by a relatively shallow burial depth (mostly $<1000 \mathrm{~m}$ ), low coal rank $\left(R_{0, \max }<0.5 \%\right)$, and well-developed thick coal seams, although there is also some bituminous coal distributed in Western Inner Mongolia as well [2].

Since Teichmüller's comprehensive study on coal formation [3], the deposition microenvironments of coal seams within developing palaeomires have been investigated worldwide based on coal 
petrology and palynology. Haequebard and Donaldson established the four-component facies diagram using microlithotypes and assemblages of microlithotypes to distinguish various moor environments, and Marchioni further modified the components of the diagrams to analyze the coal facies [4]. Diessel first systematically discussed the diagnostic values of different macerals for paleo-environmental interpretations and proposed the tissue preservation index (TPI) and gelification index (GI) $[5,6]$. Calder et al. proposed the index of groundwater influence (GWI) supported by a vegetation index (VI) to interpret the ancient peat-forming ecosystems of Pennsylvanian bituminous coals in Nova Scotia, Canada [7]. Later, Kalkreuth et al. modified these indices for low-rank Greek Tertiary coals [8]. Further modifications have been conducted by Kalaitzidis et al., which is widely applied in low-rank coal deposits [9]. Staub proposed GWI and the cell structure preservation index (CPI) to analyze coalbed sequence architecture and marine flooding events [10]. Petersen and Ratanasthien also proposed the Wetness Index (WI) and the Tissue Index (TI) for tracking water level changes and vegetation dynamics [11]. Based on the origin and transport of macerals, several researchers have also made objections regarding the accuracy of coal facies indices and diagrams [12-15]. More recent studies have shown that these diagrams could be more accurate when combined with sedimentological, organic geochemistry and palaeontological data [16-22]. Therefore, palynology is another significant measure in the identification of paleo-phytogeography. A number of studies have analyzed the vegetation type and evaluated the paleogeography, temperature, and humidity of sediments [23-28].

Based on the sedimentary analysis, it is widely accepted that coals of the Saihantala Formation in the Erlian Basin accumulated on the littoral lake and shallow lake [29-32]. According to the geochemical and mineralogical profile patterns, the coal seam in the Shengli coalfield can be attributed to the development of a basal reduced marsh environment evolving towards a more oxidizing marsh environment in the upper part of the coal seam, which could be related to the evolution from a high water-table low moor marsh environment to a high moor marsh into an open water body with a higher detrital influence at the top of the seam [33]. Wu et al. further put forward that thick coal in the Shengli coalfield was of an allochthonous genesis, which deposited firstly in the lake delta, and then transferred to a shallow lake by slumping and turbidity, and after secondary differentiation, finally deposited as a coal seam [30]. Due to the lack of more detailed evidence, it is still ambiguous whether the coals were from allochthonous or autochthonous sources. Critical element distribution, enrichment origin, and occurrence mode in the Shengli coal deposits were also investigated based on the analyses of geochemistry, petrology, tectonic evolution, and sedimentary stratigraphy [28,33-43]. It is worth mentioning that Zhuang et al. reported that the sulfur content ranged from $0.2 \%$ to $2.5 \%$, but gave no further discussion on its genesis [33]. An investigation into the climate of the Erlian Basin in the Early Cretaceous showed that it was generally under a substropic warm humid climate according to the palynology, paleo-magnetism, linear magnetic anomalies, paleobiogeography, paleoclimatology, and geologic history [44-47].

As above mentioned, although considerable efforts have been made to generally investigate the critical element, sedimentary and environmental variations in the coal-bearing stratum, the conditions and the evolution of microenvironments during peat formation have not been discussed for the lower Cretaceous, thick coal seam in the Shengli coalfield of the Erlian Basin, China. This study presents a systematic investigation of geochemistry, coal petrology, and palynology based on the classification of vertical macrolithotypes in the coal seam. These findings are used to identify the paleogeography of coal formation, explain the intermediate sulfur content of the coal seam, analyze the paleoclimate during peat formation, and evaluate the evolution of the deposition environment of the thick coal seam.

\section{Geological Setting}

The Erlian Basin was developed on a folded and metamorphosed basement mainly composed of Palaeozoic and early Mesozoic intermediate to felsic granitic plutons, mafic to felsic volcanic rocks, and Proterozoic to Palaeozoic sediments corresponding to the southern margin of the Xing'an or Xing Meng Mongolian Orogenic Belt [48-50]. The main stage of infilling in the Erlian Basin occurred in 
the Early Cretaceous, and the entire sedimentary system of the basin corresponds to an intracontinental environment with fluvial-lacustrine, fluvial, and alluvial deposits [48]. The tectono-stratigraphic evolution of the Erlian Basin can be divided into three stages with two major unconformities: the pre-rift stage corresponding to the Jurassic to very Early Cretaceous volcanic rocks of the Qinganling Group; the syn-rift stage corresponding to the Early Cretaceous sedimentary formations of the Bayanhua Group; and the post-rift stage corresponding to the Early Cretaceous Saihantala Formation and the Late Cretaceous Erlian Formation, represented by fluvial and shallow lacustrine environments $[48,51]$. The Erlian Basin can be further divided into approximately 53 half-graben-shaped depressions (Figure 1) [32]. The Lower Cretaceous Saihantala Formation is the main coal-bearing stratum. The area of the coal-bearing region is approximately $3.5 \times 10^{4} \mathrm{~km}^{2}$. The maximum oil-immersed reflectance of coal $\left(R_{\mathrm{o}, \max }\right)$ ranges from $0.3 \%$ to $0.5 \%$, and the burial depth of the coal seam is less than $1000 \mathrm{~m}$. Two to 71 coal seams commonly occurred with maximum total thicknesses of 4-343 m and individual seam thicknesses of 1.0-277.5 $\mathrm{m}$ in different depressions [1,52].

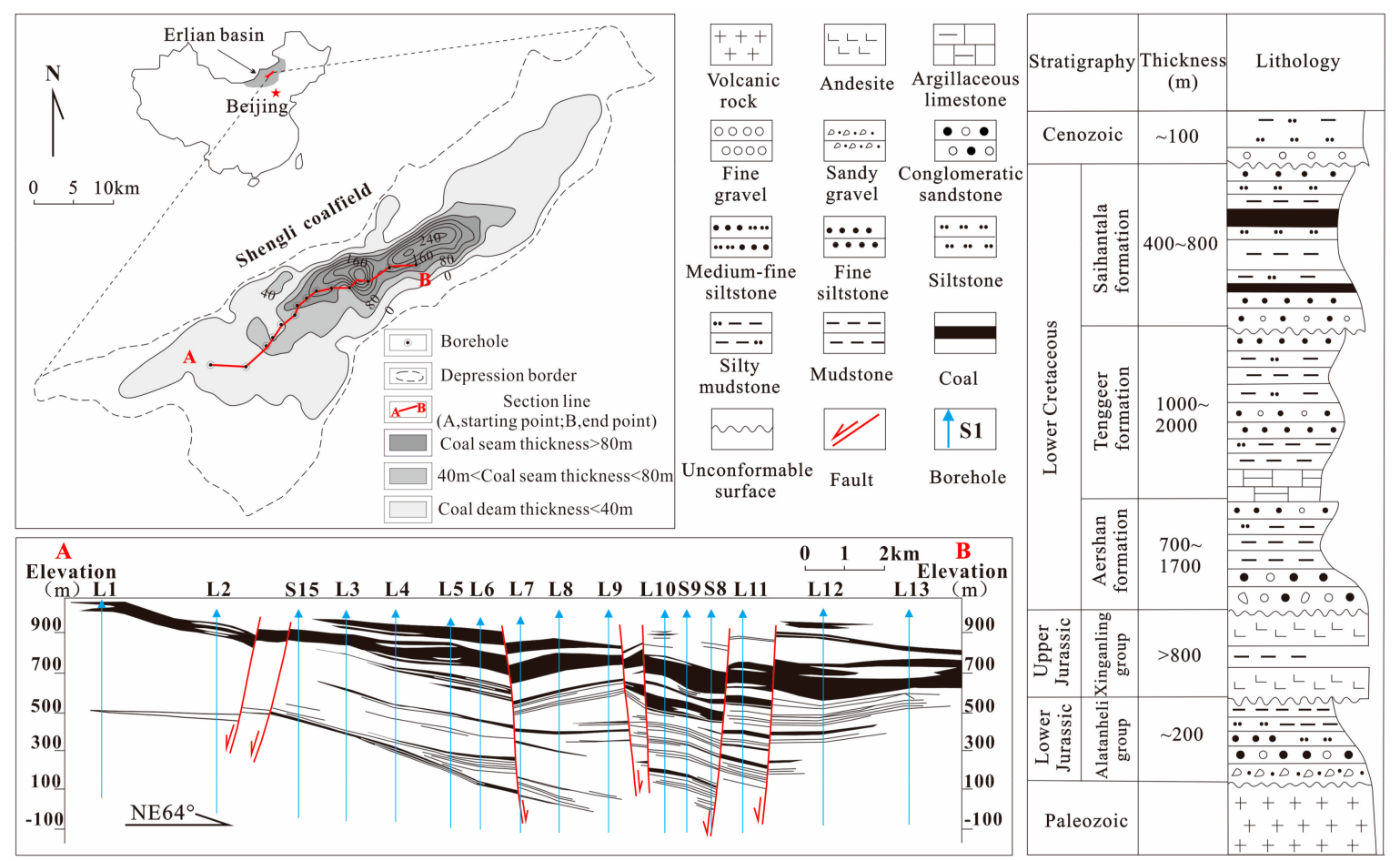

Figure 1. Location of the representative cross-section and stratigraphic column (modified from [29]). Reproduced with permission from Wang et al.; published by 2015.

The Shengli coalfield investigated in this study is located in the Jiergalangtu depression in the southeast of the Erlian Basin, and its administrative division belongs to Xilin Hot in Inner Mongolia (Figure 1). The Shengli coalfield, which is bounded by faults to the northwest and southeast, and by an erosion boundary to the northeast and southwest, is a half-graben with increased sediment thickness in the northwest (Figure 1). The coal-bearing stratum is the lower Cretaceous Saihantala Formation. Lithologically, the Saihantala Formation is composed of conglomerate, sandstone, siltstone, carbonaceous mudstone, and thick coal, and the compositional and textural maturities of sandstone and conglomerate are relatively low. The sandstone of the Saihantala Formation is mainly composed of arkose and litharenite with some poorly sorted and rounded gravel [32]. The conglomerate includes multiple size classes and is characterized by matrix-supported grains [32]. The low compositional and textural maturities indicate relatively short transportation and closeness to the source. The sedimentary facies were interpreted to include fan deltaic plain and front, braided river deltaic plain and front, and shore-shallow lake [29]. 


\section{Materials and Methods}

Samples were collected from the west No. 1 open-cast coal mine in the Shengli coalfield. To avoid the weathering influence and moisture loss, a new working face was chosen and further stripped by a digging machine for coal delineating and sampling. According to the distribution of lithotypes in the newly-exposed section of the No. 5 coal seam (total coal thickness $=16.8 \mathrm{~m}$ ), 19 layers from the roof to the floor were distinguished in Table 1 according to the Chinese standard DZ/T 000214-1997, and coal samples were collected in each layer using the bench-by-bench channel sampling method. Due to the lack of Chinese standard sampling methods for lignite petrology analysis, the coal sampling method used partially referred to the GB/T 19222-2003. The coal samples were numbered from the top down through the seam, as were following sample numbers. To prevent water loss and oxidation, the coal samples were wrapped with several layers of preservative film and packed in black polyethylene bags, which were then sealed with adhesive tape. After the samples were taken to the laboratory, they were immediately crushed into $<1 \mathrm{~mm}$ fragments and evenly divided into five portions for coal petrology, proximate, ultimate, palynological, and organic carbon isotope analyses. Huminite reflectance and maceral identification were conducted on polished coal sections using a Zeiss Axio imager microscope (ZEISS, Oberkochen, German) equipped with a $50 \times 0.85$ Epiplan-Neofluar oil-immersion objective according to the Chinese standards GB/T 6948-2008 and GB/T8899-2013 at the China University of Mining and Technology. The modified ISO 7404-5:1994 was directly adopted in the standard GB/T 6948-2008. In the Chinese standard, the standard reflectance reference materials produced in China are recommended, and the number of reflectance measurement is $\geq 30$ points while the $R_{\max } \leq 0.45 \%$, which is lower than that in the ISO 7404-5. The standard GB/T8899-2013 used was largely in accordance with the corresponding ISO 7404-3:2009, except for the repeatability limit, reproducibility requirement, and test report format.

Proximate analysis, including moisture, ash, volatile matter, and fixed carbon was performed according to Chinese standard GB/T 212-2008, consistent with ISO 11722:1999, ISO 1171:1997, and ISO 562:1998, except that the attained temperature was $900{ }^{\circ} \mathrm{C}$ within three minutes in volatile yield determination. The total sulfur content in air-dried basis $\left(S_{\mathrm{t}, \mathrm{ad}}\right)$ was determined by the coulometric titration method according to the Chinese standard GB/T 214-2007. An air-dried coal sample $(0.05 \pm 0.005 \mathrm{~g})$ with a grain size less than $0.2 \mathrm{~mm}$ was weighed (accuracy of $0.0002 \mathrm{~g})$ into a ceramic boat and covered with thin layer of tungsten trioxide, then completely oxidized into sulfur oxides at a temperature of $1150{ }^{\circ} \mathrm{C}$ with a catalyst. The $\mathrm{SO}_{2}$ was absorbed by the potassium iodide solution, the iodine produced by electrolysis of potassium iodide solution was titrated, and, finally, $S_{\mathrm{t} \text {,ad }}$ was calibrated from the amount of electricity consumed by the electrolysis. The form of sulfur was determined by GB/T 215-2008. The sulfate sulfur in air-dried basis content $\left(S_{\mathrm{s}, \mathrm{ad}}\right)$ was determined by the following procedures: First, $1 \pm 0.1 \mathrm{~g}$ (accuracy of $0.0002 \mathrm{~g}$ ) of air-dried coal sample with a grain size less than $0.2 \mathrm{~mm}$ was boiled in $\mathrm{HCl}$, and the sulfate from coal was leached and converted to a barium sulfate $\left(\mathrm{BaSO}_{4}\right)$ precipitate. Finally, $S_{\mathrm{s} \text {, ad }}$ was calculated according to the mass of $\mathrm{BaSO}_{4}$. The pyritic sulfur in air-dried basis content $\left(S_{\mathrm{p}, \mathrm{ad}}\right)$ was determined by the oxidation method. After the extraction of iron from non-iron sulfide in the coal sample by $\mathrm{HCl}$, the coal sample was further leached with dilute nitric acid, and the iron in the nitric acid leaching solution was titrated by a standard potassium dichromate solution. Accordingly, $S_{\mathrm{p}, \text { ad }}$ was calculated by the iron mass. Finally, the organic sulfur content in air-dried basis $\left(S_{\mathrm{o}, \mathrm{ad}}\right)$ was calculated by $S_{\mathrm{t}, \mathrm{ad}}-\left(S_{\mathrm{t}, \mathrm{ad}}+S_{\mathrm{t}, \mathrm{ad}}\right)$.

X-ray fluorescence (XRF) spectrometry (BRUKER S8 TIGER, BRUKER, Karlsruhe, Germany) was adopted to determine the major oxides, including $\mathrm{Na}_{2} \mathrm{O}, \mathrm{MgO}, \mathrm{Al}_{2} \mathrm{O}_{3}, \mathrm{SiO}_{2}, \mathrm{~K} 2 \mathrm{O}, \mathrm{CaO}, \mathrm{TiO}_{2}, \mathrm{Fe}_{2} \mathrm{O}_{3}$, and elements, including $\mathrm{P}, \mathrm{S}, \mathrm{Cl}, \mathrm{Ti}, \mathrm{V}, \mathrm{Cr}, \mathrm{Mn}, \mathrm{Co}, \mathrm{Ni}, \mathrm{Cu}, \mathrm{Zn}, \mathrm{Ga}, \mathrm{As}, \mathrm{Br}, \mathrm{Rb}, \mathrm{Sr}, \mathrm{Y}, \mathrm{Zr}, \mathrm{Nb}, \mathrm{Mo}, \mathrm{Ru}, \mathrm{Pd}$, $\mathrm{Ba}, \mathrm{Ce}$, and $\mathrm{Gd}$ in the coal ash $\left(815^{\circ} \mathrm{C}\right)$ at the China University of Mining and Technology. 
Table 1. Geochemical analyses.

\begin{tabular}{|c|c|c|c|c|c|c|c|c|c|c|}
\hline \multirow[b]{2}{*}{ Sample Number } & \multicolumn{4}{|c|}{ Proximate Analysis } & \multicolumn{4}{|c|}{ Sulfur Content } & \multirow{2}{*}{$\begin{array}{l}\text { TOC } \\
\text { (wt \%) }\end{array}$} & \multirow{2}{*}{$\begin{array}{l}\delta^{13} \mathrm{C} \\
(\% \text { oo })\end{array}$} \\
\hline & $\begin{array}{c}M_{\mathrm{ad}} \\
(\mathrm{wt} \%)\end{array}$ & $\begin{array}{c}A_{\mathrm{d}} \\
(w \mathrm{wt} \%)\end{array}$ & $\begin{array}{l}V M_{\mathrm{daf}} \\
(\mathrm{wt} \%)\end{array}$ & $\begin{array}{c}F C_{\mathrm{d}} \\
(\text { wt \%) }\end{array}$ & $\begin{array}{c}S_{\mathrm{t.d}} \\
(\mathrm{wt} \%)\end{array}$ & $\begin{array}{c}S_{\mathrm{p} . \mathrm{d}} \\
(\mathrm{wt} \%)\end{array}$ & $\begin{array}{c}S_{\text {s.d }} \\
(w t \%)\end{array}$ & $\begin{array}{c}S_{\text {o.d }} \\
(w t \%)\end{array}$ & & \\
\hline 1 & 20.1 & 21.4 & 48.0 & 40.9 & 1.64 & 0.69 & 0.08 & 0.87 & 65.22 & -22.88 \\
\hline 2 & 27.0 & 16.3 & 50.9 & 41.1 & 2.00 & 1.12 & 0.07 & 0.81 & 61.91 & -22.07 \\
\hline 3 & 33.5 & 14.6 & 47.0 & 45.2 & 1.07 & 0.21 & 0.03 & 0.83 & 62.67 & -21.83 \\
\hline 4 & 28.4 & 19.0 & 48.7 & 41.6 & 1.90 & 0.75 & 0.15 & 1.00 & 63.32 & -22.04 \\
\hline 5 & 21.1 & 6.6 & 48.6 & 48.0 & 0.81 & 0.13 & 0.05 & 0.63 & 64.00 & -22.04 \\
\hline 6 & 23.2 & 30.7 & 50.8 & 34.1 & 0.95 & 0.16 & 0.08 & 0.71 & 63.75 & -21.99 \\
\hline 7 & 27.9 & 10.9 & 63.4 & 32.6 & 0.72 & 0.03 & 0.04 & 0.65 & 62.75 & -22.66 \\
\hline 8 & 17.8 & 41.0 & 45.4 & 32.2 & 0.64 & 0.12 & 0.05 & 0.47 & 71.69 & -22.13 \\
\hline 9 & 22.8 & 8.0 & 52.5 & 43.7 & 1.37 & 0.47 & 0.06 & 0.84 & 65.02 & -23.42 \\
\hline 10 & 20.6 & 19.9 & 48.2 & 41.5 & 0.98 & 0.23 & 0.08 & 0.67 & 66.19 & -23.34 \\
\hline 11 & 31.2 & 7.5 & 45.7 & 50.2 & 1.11 & 0.03 & 0.03 & 1.05 & 65.96 & -23.36 \\
\hline 12 & 25.4 & 14.2 & 58.9 & 35.3 & 0.71 & 0.01 & 0.03 & 0.67 & 68.87 & -23.07 \\
\hline 13 & 26.6 & 7.1 & 52.3 & 44.4 & 1.96 & 0.86 & 0.15 & 0.95 & 66.05 & -22.52 \\
\hline 14 & 21.6 & 21.1 & 67.6 & 25.6 & 0.87 & 0.15 & 0.03 & 0.69 & 62.48 & -22.67 \\
\hline 15 & 21.3 & 7.4 & 44.6 & 51.3 & 0.81 & 0.00 & 0.00 & 0.81 & 63.30 & -22.18 \\
\hline 16 & 20.2 & 7.4 & 46.9 & 49.2 & 1.17 & 0.38 & 0.05 & 0.74 & 88.64 & -23.12 \\
\hline 17 & 20.1 & 20.1 & 62.1 & 30.3 & 0.65 & 0.05 & 0.03 & 0.57 & 62.03 & -22.64 \\
\hline 18 & 26.9 & 22.0 & 49.0 & 39.8 & 0.97 & 0.10 & 0.08 & 0.79 & 64.11 & -22.28 \\
\hline 19 & 36.5 & 9.3 & 48.6 & 46.6 & 0.93 & 0.03 & 0.00 & 0.90 & 68.15 & -21.92 \\
\hline Average & 24.9 & 16.0 & 51.5 & 40.7 & 1.12 & 0.29 & 0.06 & 0.77 & 66.11 & -22.53 \\
\hline
\end{tabular}

VM: volatile matter; FC: fixed carbon; M: moisture; d dried basis; ad: air dried basis; daf: dried ash free basis; $S_{\text {t.d }}$ : total sulfur content; $S_{\text {p.d }}:$ pyritic sulfur content; $\mathrm{S}_{\mathrm{s.d}}$ : sulfate sulfur content; S: organic sulfur content; TOC: total organic carbon. 
Organic carbon isotopes were analyzed using a Thermo Delta V plus + Flash EA HT at the Nanjing Institute of Geology and Paleontology, Chinese Academy of Sciences. Samples were sequentially prepared in excess of $10 \%$ hydrochloric acid followed by the addition of hydrofluoric acid, water, hydrochloric acid, and water. $\mathrm{CO}_{2}$ collected from the fully burnt samples at $850{ }^{\circ} \mathrm{C}$ was separated, purified, and measured in the isotope mass spectrometer. Carbon black (GBW04407) with a carbon isotope of $-22.43 \%$ oo \pm 0.07 was adopted as the standard reference material. The reproducibility of the result was $\geq 0.2 \%$. Organic and pyritic sulfur isotopes from three samples were also measured at the above institute using a Delta V Advantage Isotope Ratio MS (Thermo Fisher Scientific, Waltham, MA, USA). Seven samples used in the palynology analysis were disaggregated using hydrochloric acid-hydrogen fluoride, and the fossils were identified under a microscope at the Nanjing Institute of Geology and Paleontology, Chinese Academy of Sciences.

\section{Results}

\subsection{Proximate Analyses and Coal Geochemistry}

The results of the proximate and sulfur analyses of the 19 samples are shown in Table 1 and Figure 2. The proximate analysis results showed that the studied coals displayed a low to high ash yield which ranged from $6.6 \mathrm{wt} \%$ to $41.0 \mathrm{wt} \%$ (average $=24.9 \mathrm{wt} \%$ ). The air-dried moisture content $\left(M_{\mathrm{ad}}\right)$ ranged from $17.8 \mathrm{wt} \%$ to $36.5 \mathrm{wt} \%$ (average $=16.0 \mathrm{wt} \%$ ). The dried ash-free volatile matter $\left(V M_{\text {daf }}\right)$ ranged from $44.6 \mathrm{wt} \%$ to $67.6 \mathrm{wt} \%$ (average $=51.5 \mathrm{wt} \%$ ). The dried fixed carbon content $\left(F C_{\mathrm{d}}\right)$ ranged from $44.6 \mathrm{wt} \%$ to $51.3 \mathrm{wt} \%$ (average $=40.7 \mathrm{wt} \%$ ). The total sulfur content ranged from $0.64 \mathrm{wt} \%$ to $2.00 \mathrm{wt} \%$ (average $=1.12 \mathrm{wt} \%$ ). The contents of pyrite, sulfate, and organic sulfur ranged from $0 \mathrm{wt} \%$ to $1.12 \mathrm{wt} \%$ (average $=0.29 \mathrm{wt} \%$ ), $0 \mathrm{wt} \%$ to $0.15 \mathrm{wt} \%$ (average $=0.057 \mathrm{wt} \%$ ), and $0.47 \mathrm{wt} \%$ to $1.05 \mathrm{wt} \%$ (average $=0.77 \mathrm{wt} \%$ ), respectively. The $\delta^{13} \mathrm{C}$ values ranged from $-23.42 \%$ to $-21.83 \%$ (average $=-22.53 \%$; Table 1 ).
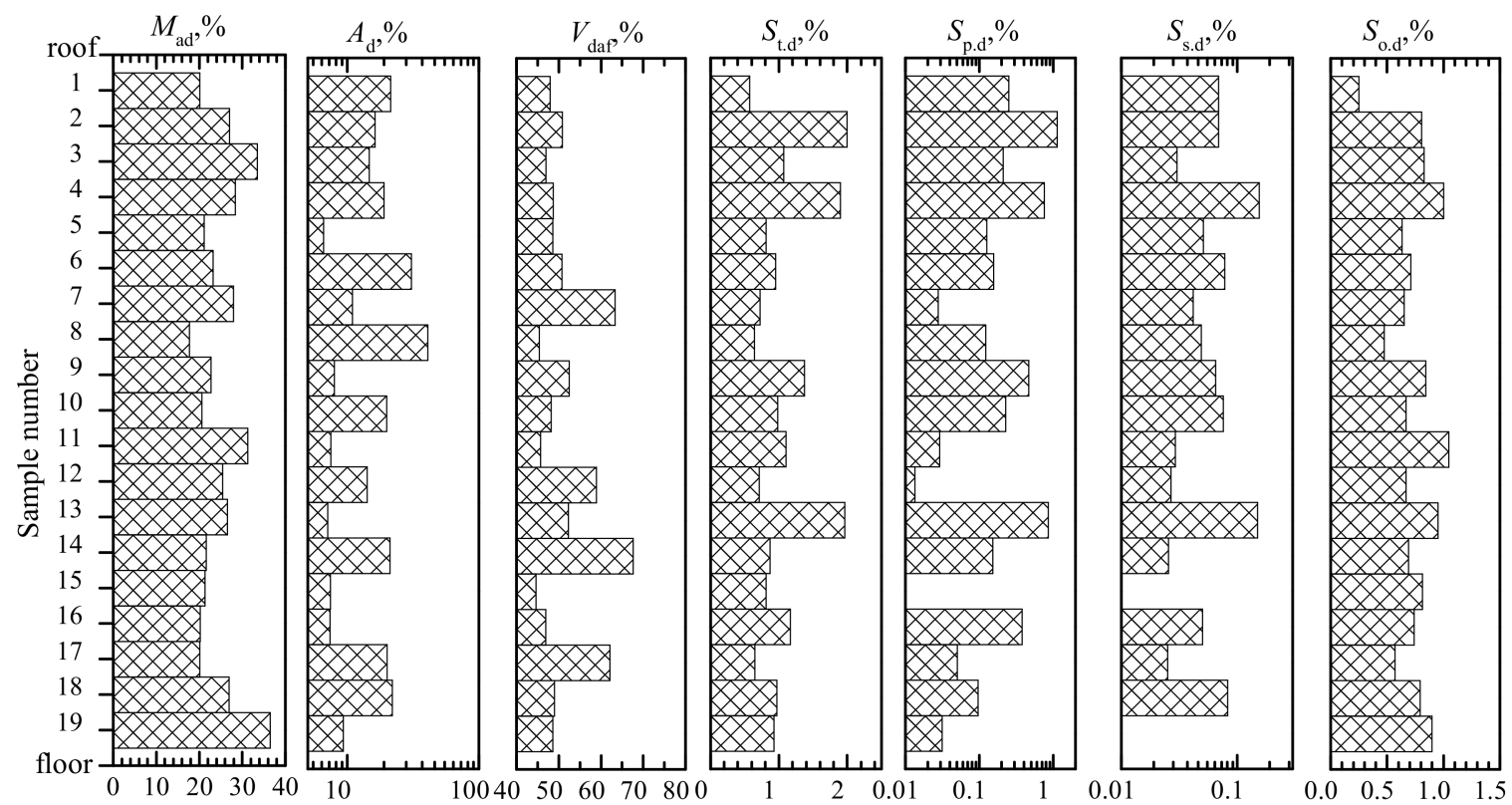

Figure 2. Proximate and sulfur analyses.

The $\mathrm{Cl}, \mathrm{Ti}, \mathrm{V}, \mathrm{Cr}, \mathrm{Co}, \mathrm{Ni}, \mathrm{Cu}, \mathrm{Ga}, \mathrm{As}, \mathrm{Br}, \mathrm{Rb}, \mathrm{Y}, \mathrm{Nb}, \mathrm{Mo}, \mathrm{Ru}, \mathrm{Pd}, \mathrm{Ce}$, and $\mathrm{Gd}$ elements were rare and occurred in several coal samples ranging from 3.7-730 ppm (Table 2). In contrast, the other elements, including $\mathrm{P}, \mathrm{S}, \mathrm{Mn}, \mathrm{Zn}, \mathrm{Sr}, \mathrm{Ba}$, and oxides including $\mathrm{Na}_{2} \mathrm{O}, \mathrm{MgO}, \mathrm{Al}_{2} \mathrm{O}_{3}, \mathrm{SiO}_{2}, \mathrm{~K}_{2} \mathrm{O}, \mathrm{CaO}, \mathrm{TiO}_{2}$, and $\mathrm{Fe}_{2} \mathrm{O}_{3}$, were widely developed in various coal samples. The contents of $\mathrm{P}, \mathrm{S}, \mathrm{Mn}, \mathrm{Zn}, \mathrm{Sr}, \mathrm{Zr}$, and $\mathrm{Ba}$ ranged from 180 to 6610 ppm, 9220 to 122,400 ppm, 50 to 3810 ppm, 30 to 544 ppm, 105 to 2374 ppm, 
10 to 3782 ppm, and 240 to 4420 ppm, respectively. The contents of $\mathrm{Na}_{2} \mathrm{O}, \mathrm{MgO}, \mathrm{Al}_{2} \mathrm{O}_{3}, \mathrm{SiO}_{2}, \mathrm{~K}_{2} \mathrm{O}$, $\mathrm{CaO}, \mathrm{TiO}_{2}$ and $\mathrm{Fe}_{2} \mathrm{O}_{3}$ ranged from $0.7-7.0 \%, 0.2-12.8 \%, 2.5-21.6 \%, 4.4-56.3 \%, 0.3-2.7 \%, 1.1-25.5 \%$, $0.1-0.8 \%$, and $0.6-45.8 \%$, respectively. Figure 3 further shows that most of the coal samples from the Shengli coalfield were enriched with $\mathrm{Na}_{2} \mathrm{O}, \mathrm{MgO}, \mathrm{K}_{2} \mathrm{O}$, and $\mathrm{CaO}$, and several samples were enriched with $\mathrm{Cr}$, $\mathrm{Co}, \mathrm{Ni}, \mathrm{Cu}, \mathrm{Zn}, \mathrm{As}, \mathrm{Rb}, \mathrm{Sr}, \mathrm{Nb}, \mathrm{Mo}, \mathrm{Ba}$, and $\mathrm{Gd}$, but were depleted in $\mathrm{Al}_{2} \mathrm{O}_{3}, \mathrm{SiO}_{2}, \mathrm{TiO}_{2}, \mathrm{Fe}_{2} \mathrm{O}_{3}$, $\mathrm{Cl}, \mathrm{V}, \mathrm{Co}, \mathrm{Ga}, \mathrm{Y}$, and $\mathrm{Ce}$ when compared to those from the average Chinese coals [53,54].

Table 2. Elemental concentrations in coal samples from the Shengli coal deposits.

\begin{tabular}{|c|c|c|c|c|c|c|c|c|c|c|c|c|c|c|c|c|c|}
\hline \multirow{2}{*}{ Sample Number } & \multicolumn{8}{|c|}{ Oxides (\%) } & \multicolumn{9}{|c|}{ Elements (ppm) } \\
\hline & $\mathrm{Na}_{2} \mathrm{O}$ & $\mathrm{MgO}$ & $\mathrm{Al}_{2} \mathrm{O}_{3}$ & $\mathrm{SiO}_{2}$ & $\mathrm{~K}_{2} \mathrm{O}$ & $\mathrm{CaO}$ & $\mathrm{TiO}_{2}$ & $\mathrm{Fe}_{2} \mathrm{O}_{3}$ & $\mathbf{P}$ & $S$ & $\mathrm{Cl}$ & $\mathrm{Ti}$ & $\mathrm{V}$ & $\mathrm{Cr}$ & Mn & Co & $\mathrm{Ni}$ \\
\hline 1 & 2.5 & 4.0 & 20.2 & 47.3 & 2.1 & 7.7 & 0.8 & 5.6 & 210 & 39550 & n.d. & n.d. & 140 & 140 & 210 & n.d. & n.d. \\
\hline 2 & 7.0 & 7.9 & 13.6 & 8.3 & 0.6 & 21.1 & 0.5 & 13.5 & n.d. & 122400 & n.d. & n.d. & 140 & 170 & 322 & n.d. & n.d. \\
\hline 4 & 0.4 & 0.2 & 5.3 & 18.4 & 0.3 & 1.1 & 0.2 & 0.6 & 517 & 9220 & 140 & n.d. & n.d. & n.d. & 50 & n.d. & n.d. \\
\hline 5 & 3.2 & 10.2 & 13.9 & 12.1 & 0.7 & 24.2 & 0.4 & 5.4 & 470 & 86350 & 130 & n.d. & n.d. & n.d. & 556 & n.d. & n.d. \\
\hline 6 & 0.4 & 1.4 & 9.0 & 21.5 & 1.1 & 2.3 & 0.3 & 1.6 & 210 & 11000 & 180 & n.d. & n.d. & 40 & 80 & n.d. & 20 \\
\hline 7 & 2.5 & 10.1 & 14.6 & 21.5 & 1.5 & 20.0 & 0.5 & 4.1 & 4610 & 74540 & 120 & n.d. & 130 & 100 & 771 & n.d. & n.d. \\
\hline 10 & 0.4 & 1.1 & 5.1 & 12.2 & 0.5 & 2.2 & 0.2 & 1.2 & 210 & 11800 & 280 & n.d. & n.d. & n.d. & 144 & n.d. & 20 \\
\hline 11 & 3.4 & 12.6 & 8.9 & 7.2 & 0.5 & 25.5 & 0.4 & 3.5 & 854 & 116600 & n.d. & n.d. & n.d. & n.d. & 1080 & n.d. & n.d. \\
\hline 12 & 2.4 & 6.9 & 18.7 & 36.7 & 1.8 & 12.8 & 0.6 & 4.2 & 1230 & 53240 & n.d. & n.d. & n.d. & n.d. & 522 & n.d. & n.d. \\
\hline 13 & 4.7 & 9.4 & 15.0 & 6.5 & 0.5 & 21.8 & 0.2 & 9.3 & 400 & 108300 & n.d. & n.d. & 110 & n.d. & 625 & n.d. & n.d. \\
\hline 14 & 0.4 & 1.1 & 4.0 & 5.8 & 0.3 & 2.6 & 0.2 & 0.6 & 180 & 11500 & 210 & n.d. & 30 & n.d. & 80 & n.d. & n.d. \\
\hline 15 & 4.6 & 9.5 & 13.8 & 11.8 & 0.7 & 20.9 & 0.5 & 4.3 & 1050 & 94110 & n.d. & n.d. & 190 & n.d. & 492 & n.d. & n.d. \\
\hline 16 & 3.5 & 12.8 & 9.3 & 10.4 & 0.6 & 24.9 & 0.3 & 9.1 & 1770 & 107700 & 130 & n.d. & n.d. & n.d. & 817 & n.d. & n.d. \\
\hline Sample Number & $\mathrm{Cu}$ & $\mathrm{Zn}$ & $\mathrm{Ga}$ & As & $\mathrm{Br}$ & $\mathbf{R b}$ & $\mathrm{Sr}$ & $Y$ & $\mathrm{Zr}$ & $\mathrm{Nb}$ & Mo & $\mathbf{R u}$ & $P d$ & Ba & $\mathrm{Ce}$ & Gd & \\
\hline 1 & n.d. & 225 & n.d. & n.d. & n.d. & 104 & 750 & n.d. & 130 & n.d. & n.d. & n.d. & n.d. & 380 & n.d. & n.d. & \\
\hline 2 & n.d. & 391 & n.d. & 188 & n.d. & n.d. & 1810 & 30 & 195 & n.d. & n.d. & n.d. & 140 & 440 & n.d. & n.d. & \\
\hline 3 & n.d. & 544 & n.d. & 261 & n.d. & n.d. & 1080 & n.d. & 337 & n.d. & n.d. & n.d. & n.d. & 520 & n.d. & n.d. & \\
\hline 4 & 20 & 30 & n.d. & 10 & 20 & n.d. & 122 & n.d. & 31 & n.d. & n.d. & n.d. & n.d. & 520 & n.d. & n.d. & \\
\hline 5 & n.d. & n.d. & n.d. & n.d. & n.d. & n.d. & 1330 & n.d. & n.d. & n.d. & 100 & n.d. & n.d. & 1100 & n.d. & n.d. & \\
\hline 6 & 60 & 141 & n.d. & 10 & n.d. & 52 & 173 & n.d. & 90 & n.d. & n.d. & n.d. & n.d. & n.d. & n.d. & n.d. & \\
\hline 7 & 187 & 185 & n.d. & n.d. & n.d. & n.d. & 1450 & n.d. & 100 & n.d. & n.d. & n.d. & n.d. & 650 & n.d. & n.d. & \\
\hline 8 & n.d. & 347 & n.d. & n.d. & n.d. & 133 & 242 & n.d. & 112 & n.d. & n.d. & n.d. & n.d. & 720 & n.d. & n.d. & \\
\hline 9 & 110 & 258 & n.d. & 111 & n.d. & n.d. & 1670 & n.d. & n.d. & n.d. & n.d. & n.d. & n.d. & 490 & n.d. & n.d. & \\
\hline 10 & 30 & 107 & n.d. & n.d. & n.d. & 20 & 124 & n.d. & 28 & n.d. & 30 & n.d. & n.d. & 430 & n.d. & n.d. & \\
\hline 11 & 154 & 182 & n.d. & n.d. & n.d. & n.d. & 1820 & n.d. & 111 & n.d. & n.d. & n.d. & n.d. & 460 & n.d. & n.d. & \\
\hline 12 & n.d. & n.d. & n.d. & n.d. & n.d. & n.d. & 939 & 60 & 155 & n.d. & n.d. & n.d. & n.d. & 300 & 430 & n.d. & \\
\hline 13 & n.d. & 162 & n.d. & 730 & n.d. & n.d. & 1200 & n.d. & 373 & 225 & n.d. & n.d. & 150 & n.d. & n.d. & n.d. & \\
\hline
\end{tabular}

n.d.: not detected.

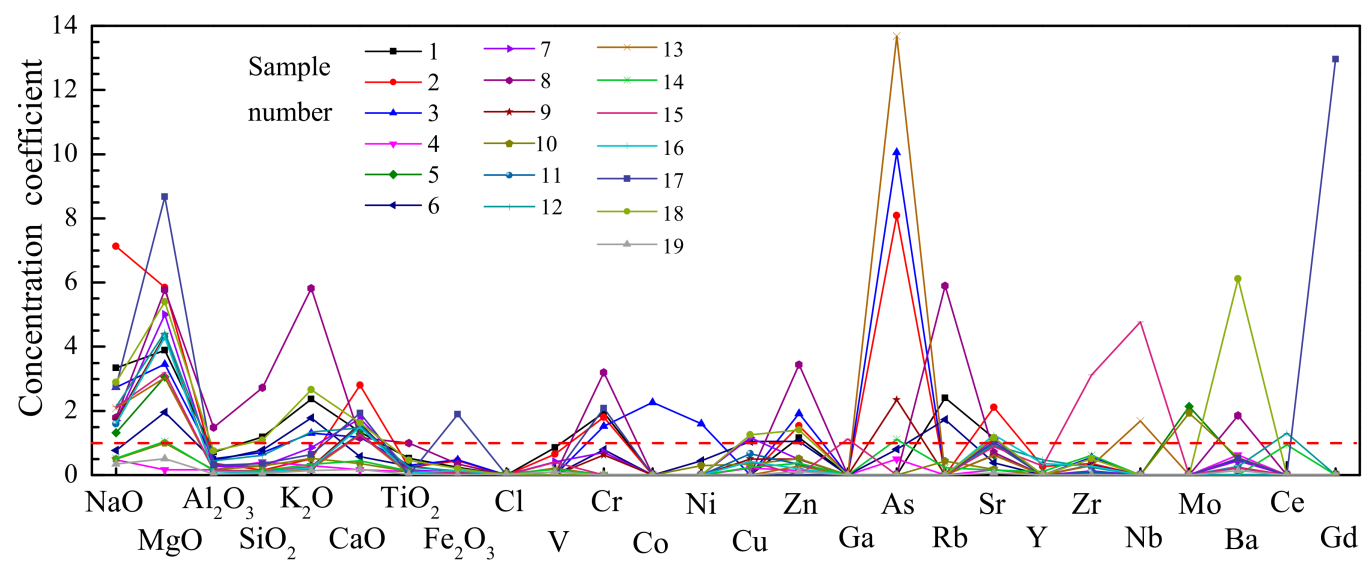

Figure 3. Concentration coefficients (CC, ratio of element concentration in investigated coals vs. average Chinese coals). 


\subsection{Coal Petrology}

The content of huminite ranged from 32.4 to 98.1 vol \% and was dominated by detrohuminite (Table 3, Figure 4). The content of attrinite ranged from 3.2 to $86.4 \mathrm{vol} \%$ (average $=20.0 \mathrm{vol} \%$ ) and that of densinite varied from 3.1 to $78.7 \mathrm{vol} \%$ (average $=46.2 \mathrm{vol} \%$ ). Textinite was only observed in sample 5 (Table 3). The ulminite content ranged from $0.3 \mathrm{vol} \%$ to $36.9 \mathrm{vol} \%$ (average $=9.3 \mathrm{vol} \%$ ) (Table 3 ). The gelohuminite content varied from 0.4 to $21.9 \mathrm{vol} \%$ (average $=4.7 \mathrm{vol} \%$ ), and the corpohuminite content ranged from $0.4 \mathrm{vol} \%$ to $9.7 \mathrm{vol} \%$ (average $2.0 \mathrm{vol} \%$ ).
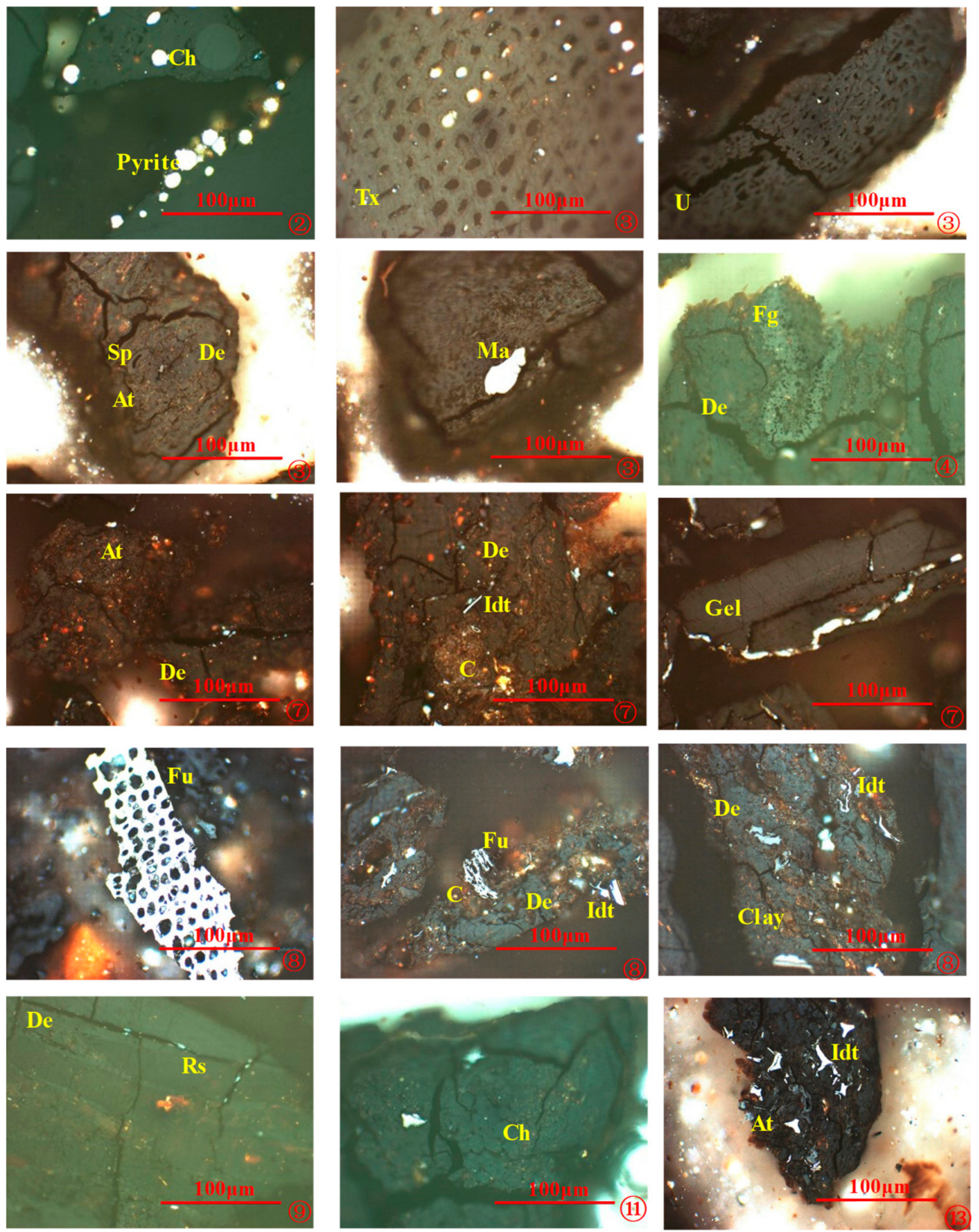

Figure 4. Macerals photos (the sample number is given at the lower right corner in each photo as red circled digit); Tx, Textinite; U, Ulminite; At, Attrinite; De, Densinite; Gh, Gelohuminite; $\mathrm{Ch}$, Corpohuminite; Fu, Fusinite; Ma, Macrinite; Idt, Inertodetrinite; Sp, Sporinite; Cu, Cutinite; Rs, Resinite. 
Table 3. Maceral composition.

\begin{tabular}{|c|c|c|c|c|c|c|c|c|c|c|c|c|c|c|c|c|c|}
\hline \multirow{2}{*}{$\begin{array}{l}\text { Sample } \\
\text { Number }\end{array}$} & \multirow{2}{*}{$\begin{array}{l}\text { Macroscopic } \\
\text { Description }\end{array}$} & \multirow{2}{*}{$\begin{array}{l}\text { Layer Thickness } \\
\text { (m) }\end{array}$} & \multirow{2}{*}{$\begin{array}{c}\overline{R_{\text {ran }}} \\
(\%)\end{array}$} & \multicolumn{6}{|c|}{ Huminite (vol \%) } & \multicolumn{5}{|c|}{ Inertinite (vol \%) } & \multicolumn{3}{|c|}{ Liptinite (vol \%) } \\
\hline & & & & Tx & $\mathrm{U}$ & At & De & Gh & Ch & Fu & Sf & Ma & $\mathrm{Fg}$ & Idt & $S p$ & $\mathrm{Cu}$ & Rs \\
\hline 1 & Dull coal & 1.90 & 0.27 & n.d. & 4.6 & 13.1 & 35.1 & 6.9 & 0.0 & 20.5 & 1.9 & 2.7 & 0.0 & 14.7 & 0.0 & 0.0 & 0.4 \\
\hline 2 & Semidull coal & 2.68 & 1 & n.d. & 8.2 & 6.5 & 74.3 & 3.1 & 3.1 & 0.3 & 0.3 & 0.0 & 1.0 & 0.3 & 1.7 & 0.3 & 0.7 \\
\hline 3 & Semibright coal & 2.75 & 0.27 & n.d. & 0.3 & 86.4 & 3.1 & 1.4 & 1.7 & 0.7 & 0.0 & 0.0 & 2.4 & 0.7 & 3.1 & 0.0 & 0.3 \\
\hline 4 & Bright coal & 1.00 & 1 & n.d. & 36.9 & 19.9 & 33.2 & 1.1 & 0.4 & 4.1 & 0.7 & 0.4 & 1.1 & 1.8 & 0.0 & 0.0 & 0.4 \\
\hline 5 & Semibright coal & 0.60 & / & 3.8 & 17.7 & 9.0 & 38.9 & 21.9 & 0.7 & 2.4 & 0.7 & 0.0 & 0.0 & 1.7 & 0.3 & 0.0 & 2.8 \\
\hline 6 & Bright coal & 0.90 & 1 & n.d. & 4.7 & 13.0 & 73.6 & 0.0 & 0.4 & 2.9 & 0.7 & 1.1 & 0.0 & 2.2 & 0.0 & 0.0 & 1.4 \\
\hline 7 & Semibright coal & 1.40 & 1 & n.d. & 19.0 & 17.0 & 29.8 & 8.0 & 9.7 & 3.8 & 0.3 & 0.0 & 0.0 & 3.5 & 4.5 & 0.3 & 4.2 \\
\hline 8 & Dull coal & 0.65 & / & n.d. & 2.7 & 3.2 & 24.3 & 1.1 & 1.1 & 52.4 & 0.5 & 2.2 & 0.0 & 11.9 & 0.0 & 0.0 & 0.5 \\
\hline 9 & Bright coal & 0.57 & 1 & n.d. & 6.1 & 58.9 & 14.2 & 11.0 & 2.9 & 0.3 & 0.3 & 0.0 & 2.9 & 0.0 & 3.2 & 0.0 & 0.0 \\
\hline 10 & Dull coal & 0.62 & 0.29 & n.d. & 2.4 & 5.4 & 50.0 & 3.0 & 0.7 & 19.9 & 0.7 & 0.7 & 0.0 & 16.9 & 0.0 & 0.0 & 0.3 \\
\hline 11 & Bright coal & 0.26 & / & n.d. & 0.3 & 10.8 & 73.0 & 2.7 & 5.7 & 4.1 & 0.0 & 0.0 & 0.3 & 0.0 & 1.0 & 0.0 & 2.0 \\
\hline 12 & Dull coal & 0.21 & 0.26 & n.d. & 6.3 & 10.4 & 45.1 & 6.3 & 6.3 & 11.1 & 0.3 & 2.4 & 1.0 & 5.9 & 2.4 & 0.0 & 2.4 \\
\hline 13 & Semidull coal & 0.07 & 1 & n.d. & 8.5 & 3.5 & 78.7 & 3.2 & 0.7 & 1.4 & 0.4 & 1.1 & 1.1 & 0.4 & 0.4 & 0.0 & 0.7 \\
\hline 14 & Semibright coal & 0.20 & / & n.d. & 36.4 & 8.5 & 39.0 & $\begin{array}{l}3.2 \\
8.9\end{array}$ & 2.0 & $\begin{array}{l}1.4 \\
0.7\end{array}$ & 0.0 & $\begin{array}{l}1.1 \\
0.3\end{array}$ & $\begin{array}{l}1.1 \\
0.0\end{array}$ & 0.0 & $\begin{array}{l}0.4 \\
2.3\end{array}$ & 0.0 & 2.0 \\
\hline 15 & Bright coal & 0.19 & 0.28 & n.d. & 4.1 & 64.2 & 23.7 & 5.4 & 0.7 & 0.7 & 0.0 & 0.0 & 0.3 & 0.3 & 0.7 & 0.0 & 0.0 \\
\hline 16 & Semibright coal & 0.57 & 1 & n.d. & 3.3 & 11.0 & 75.7 & 1.5 & 0.0 & 4.8 & 0.7 & 0.7 & 0.0 & 0.7 & 0.7 & 0.0 & 0.7 \\
\hline 17 & Dull coal & 0.50 & 0.27 & n.d. & 2.9 & 9.5 & 50.9 & 0.4 & 0.4 & 18.7 & 3.7 & 9.9 & 0.0 & 2.9 & 0.0 & 0.0 & 0.7 \\
\hline 18 & Seimdull coal & 0.49 & 1 & n.d. & 4.1 & 6.8 & 53.7 & 2.0 & 2.0 & 19.6 & 3.0 & 0.7 & 0.0 & 3.7 & 2.4 & 0.0 & 2.0 \\
\hline 19 & Bright coal & 1.20 & 0.27 & n.d. & 7.3 & 22.4 & 61.5 & 1.0 & 0.0 & 2.8 & 0.7 & 0.3 & 0.0 & 3.1 & 0.0 & 0.0 & 0.7 \\
\hline Average & & 0.88 & 0.27 & 0.2 & 9.3 & 20.0 & 46.2 & 4.7 & 2.0 & 9.0 & 0.8 & 1.2 & 0.5 & 3.7 & 1.2 & 0.0 & 1.2 \\
\hline
\end{tabular}

Tx Textinite; U Ulminite; At Attrinite; De Densinite; Gh Gelohuminite; Ch Corpohuminite; Fu Fusinite; Sf Semifusinite; Ma Macrinite; Fg Funginite; Idt Inertodetrinite; Sp Sporinite; Cu Cutinite; Rs Resinite 
The content of inertinite varied from 1.0 to $67.0 \mathrm{vol} \%$ and primarily consisted of fusinite (from 0.3 to $52.4 \mathrm{vol} \%$, average $=9.0 \mathrm{vol} \%$ ) (Table 3, Figure 4 ). The semifusinite content ranged from 0.3 to $3.7 \mathrm{vol} \%$ (average $=0.8 \mathrm{vol} \%$ ). The macrinite content ranged from 0.3 to $9.9 \mathrm{vol} \%$ (average $=1.2 \mathrm{vol} \%$ ), whereas the funginite content ranged from 0.3 to $2.9 \mathrm{vol} \%$ (average $=0.5 \mathrm{vol} \%$ ). The inertodetrinite content varied from 0.3 to 16.9 vol $\%$ (average $=3.7$ vol \%).

The content of liptinite ranged from 0.3 to $9.0 \mathrm{vol} \%$ (average $=2.4 \mathrm{vol} \%$ ) and was dominated by sporinite (from 0.3 to $4.5 \mathrm{vol} \%$; average $=1.2 \mathrm{vol} \%$ ) (Table 3, Figure 4 ). The average cutinite content was $0.03 \mathrm{vol} \%$, and the resinite content varied from 0.3 to $4.2 \mathrm{vol} \%$ (average $=1.2 \mathrm{vol} \%$ ).

The mean random huminite random reflectance ranged from 0.26 to $0.29 R_{\text {ran }}(\%)$ (average $=0.27 \%$; Table 3), which can be classified as low-rank B (lignite B) according to ISO 11760:2005.

\subsection{Palynology}

Samples 3, 5, 8, 10, 17, and 18 exhibited sporo-pollen assemblages that primarily included Cicatricosisporites, Cyathidites, Gleicheniidites, Laevigatosporites, Classopollis, Dictyotriletes speciosus, Kuylisporites kunaris, and Foraminisporis asymmetricus, which were common in the Early Cretaceous (Figure 5, Table 4) [55]. Cicatricosisporites are characterized by a fine strip surface and non-fusion corner of spores, such as Cicatricosi sporitesminor, Cictricosisporites australiensis, Cicatricosisporites amalocostriatus, and Cicatricosisporites mimutaestriatus. The identified sporo-pollens are mainly from pteridophyta and gymnospermae, as well as a small quantity of bryophyte and algae. The proportion of spores generally increased from 15-79\%, whereas that of pollen decreased from the bottom to the top of the coal seam from $52-16 \%$ (Table 4). The sporo-pollens at the bottom part of the coal seam was dominated by gymnospermae, mainly conifers; whereas those of the top part of the coal seam was dominated by pteridophyta, mainly cyatheaceae (Table 4). Furthermore, the counting changes of pollen does not match its proportion. From bottom to top, the counting of spores increased, except in sample 5, while pollen counting also increased, except in samples 3 and 5. Nevertheless, pteridophyta were, in general, a flourishing trend from the bottom to top.

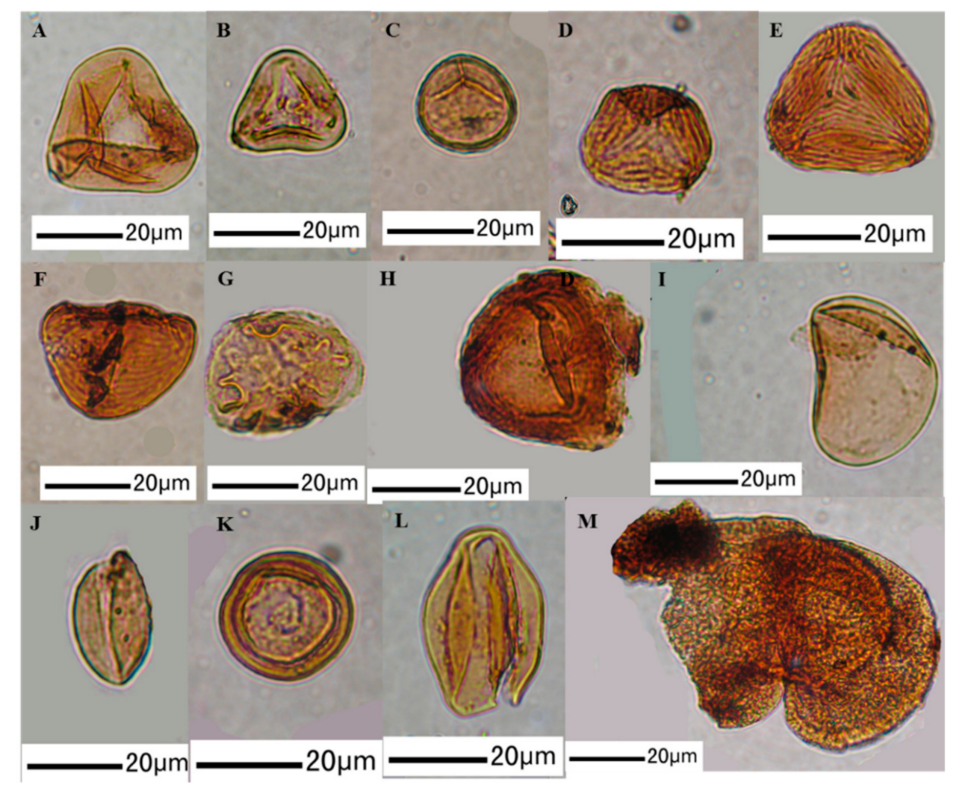

Figure 5. Sporomorphs of the coal samples (A-H) are from the No. 3 coal sample; (I) is from No.5 coal sample; (J-K) are from the No. 8 coal sample; $(\mathbf{L})$ and $(\mathbf{M})$ are from the No. 10 and 12 coal samples, respectively: (A) Cyathidites minor; (B) Gleicheniidites senoicus; (C) Leptolepidites psarosus; (D) Cicatricosisporites minor; (E) Cictricosisporites australiensis; (F) Cicatricosisporites amalocostriatus;

(G) Kuylisporites lunaris; (H) Bayanhuasporites membranceus; (I) Laevigatosporites ovatus; (J) Cycadopites acerrimus;

(K) Classopollisannulatus; (L) Eucommiidites troedsoni; and (M) Podocarpidites sp from the No. 12 coal sample. 
Table 4. Statistics of sporo-pollen in the No.5 coal seam.

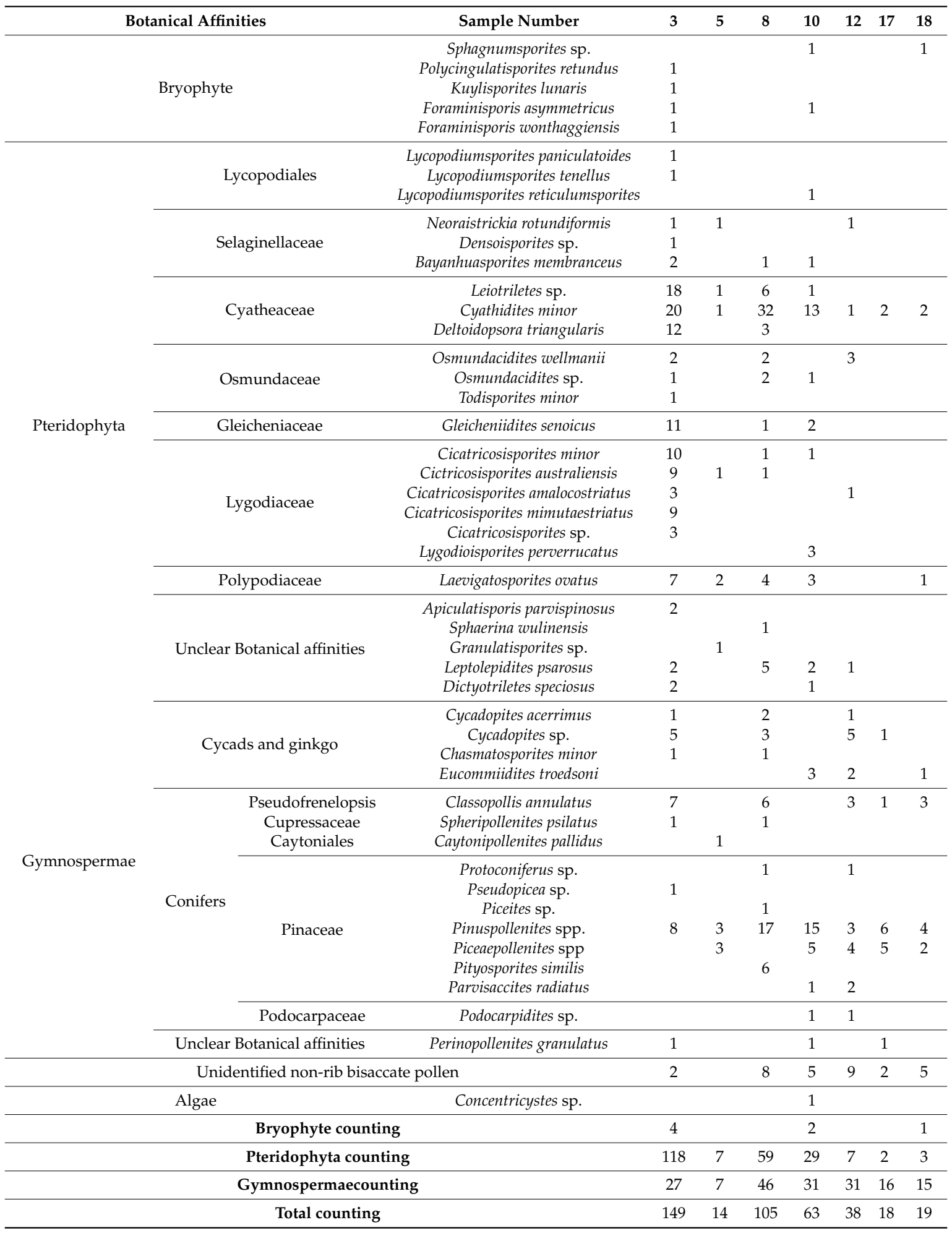

\section{Discussion}

\subsection{Depositional Environment of the Peat}

Based on the critical facies precursors of maceral subgroups [3], samples of the No. 5 coal seam lacking telohuminite and rich in detrohuminite were characterized by the dominance of herbaceous 
plants in a lakeshore (e.g., reed-mire). Mukhopadhyay developed a diagram to identify the origin of the main vegetation type in the palaeomire, and oxic/anoxic conditions prevailed during peat accumulation [56]. Figure 6 shows that the studied coal samples were mostly projected on the area closer to apex B; only the no. 8 samples did not follow this trend due to higher inertinite contents. This finding indicates that the peat accumulated under anoxic conditions associated with bacterial activity, occasionally alternating with partially oxidative ones. Additionally, the scattered distribution in the ternary plot inferred that the groundwater level during peat accumulation generally seems to have been highly fluctuating in the palaeomire.

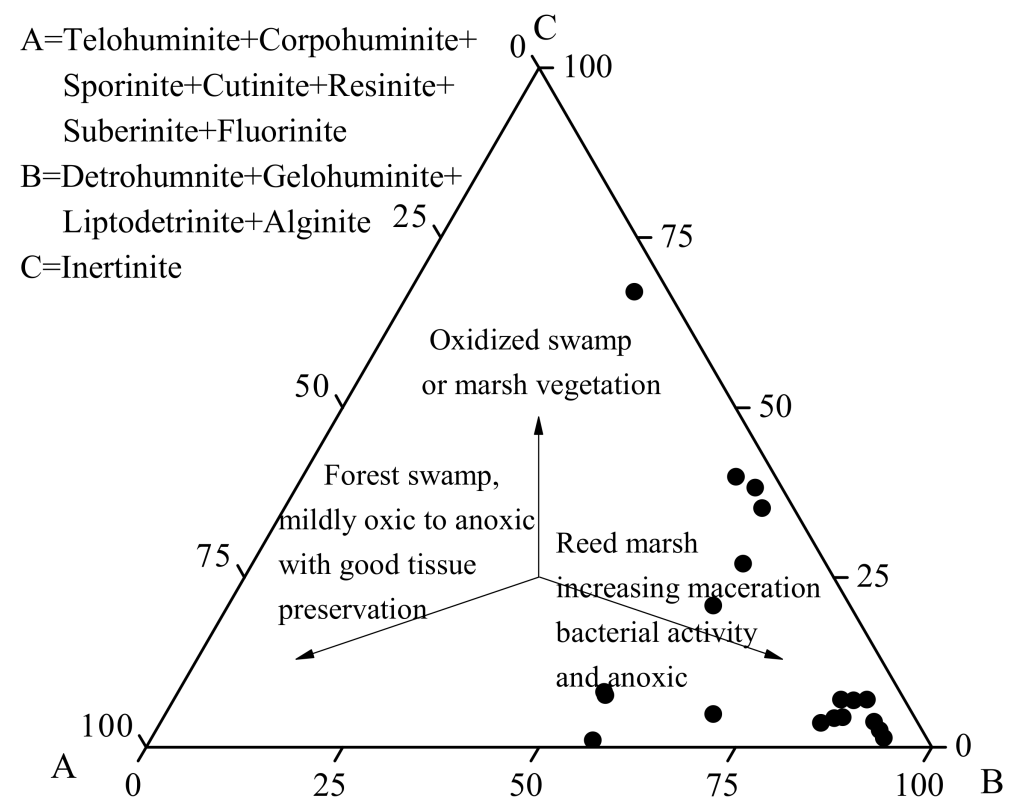

Figure 6. ABC ternary plot of the studied Shengli coal samples (after [56]). Reproduced with permission from Mukhopadhyay; published by 1989.

The TPI, GI, GWI, and VI calculated from the maceral analysis were also adopted to interpret the paleo-environment of peat accumulation. These indices were originally developed in studies on bituminous coals in Australia and Canada [5,7]. In this study, the indices modified by Kalaitzidis et al. were adopted to assess the coal facies and depositional environments of the Shengli coals $[9,57]$. The low TPI (0.03-1.39) and VI (0.05-1.42) values suggested that the herbaceous vegetation was predominant, with relatively low levels of oxygen and low preservation of organic matter during accumulation, except sample no. 8 (Figures 7 and 8) [58]. Moderate and variable GI (0.05-11.59) and GWI (0.07-14.72) values mainly inferred a moderate influence of groundwater during accumulation; thus, mesotrophic to rheotrophic conditions with a relatively high supply of inorganic material and fluctuating water table dominated the coal deposit. This conclusion was further verified by the relatively high ash yields of the coals (Table 1). As stated above, the palaeomires were developed in limnic to limno-telmatic environments, and the high inertinite contents in several layers were presumably related to oxidation periods, such as a drier climate and/or a very low water-table.

Moreover, great vertical changes in typical environment indictors of mineral and element contents, such as $\mathrm{Al}_{2} \mathrm{O}_{3}, \mathrm{CaO}, \mathrm{Ti}, \mathrm{V}, \mathrm{Cr}, \mathrm{Ni}, \mathrm{Cu}, \mathrm{Ga}$, As, $\mathrm{Rb}, \mathrm{Sr}, \mathrm{Mo}, \mathrm{Ba}, \mathrm{Ce}, \mathrm{Rb} / \mathrm{K}, \mathrm{V} / \mathrm{Cr}, \mathrm{V} / \mathrm{Ni}, \mathrm{SiO}_{2}+\mathrm{Al}_{2} \mathrm{O}_{3}$, and $\left(\mathrm{Fe}_{2} \mathrm{O}_{3}+\mathrm{CaO}+\mathrm{MgO}\right) /\left(\mathrm{SiO}_{2}+\mathrm{Al}_{2} \mathrm{O}_{3}\right)$, showed that constant environmental changes between freshwater and brackish water, and oxidation and reduction (Table 2) [59-66]. This inferred that the water-table of the peat frequently changed and the deposition environment was possibly around the shoreline. Mo and As were enriched in herbs than those in woody plants [59,62], whereas that of $\mathrm{Al}$ was the opposite [60]. This further indicated that herbs were well developed in the studied coals and the peat was deposited in a lowland environment. Additionally, the palynological data 
showed that gymnosperms and ferns were dominant in the No. 5 coal seam. Moreover, gymnosperms were dominated by Pinuspollenites spp. and Piceaepollenites spp., which implies high land vegetation and could transport some hundred $\mathrm{km}$ far from their source via wind, and were not accepted as peat-forming plants. Therefore, peat-forming plants were mainly composed of herbs and bushes.

In summary, the palaeomires in Shengli Basin were developed in lakeshores where herbaceous and bushy helophytes were dominant, which is also consistent with the sedimentary analysis [29].

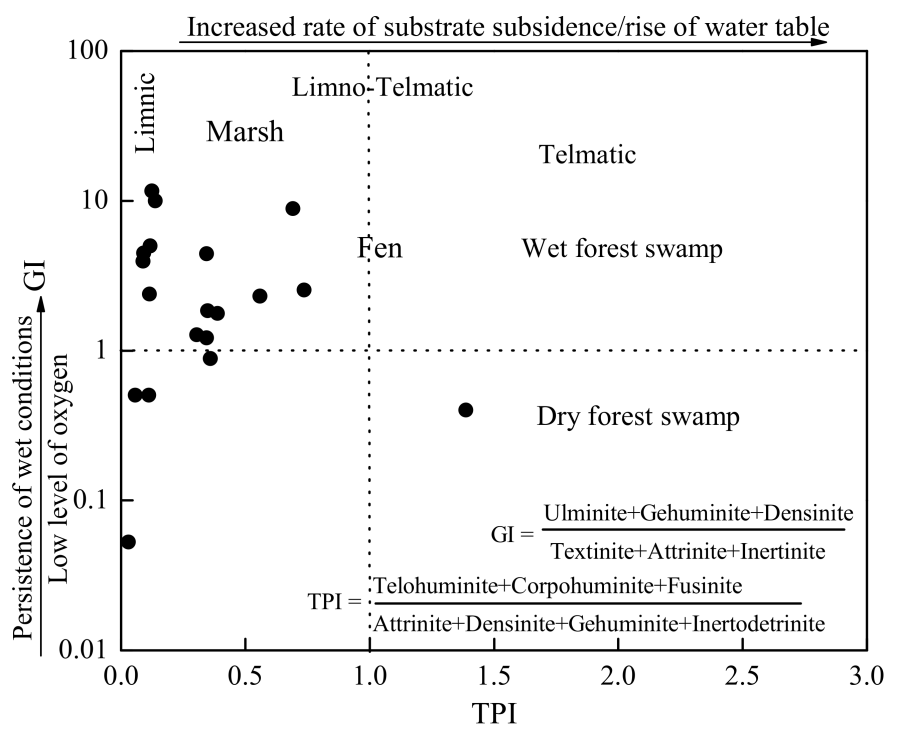

Figure 7. Plots of TPI and GI (after [9]). Reproduced with permission from Kalaitzidis et al.; published by 2004 .

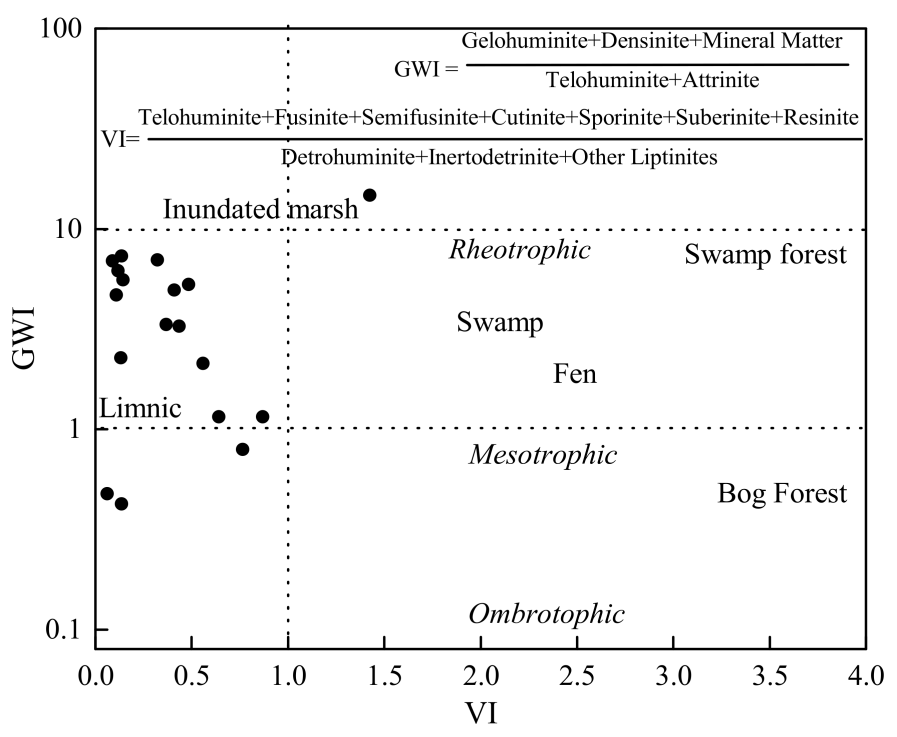

Figure 8. Plots of VI and GWI (after [9]). Reproduced with permission from Kalaitzidis et al.; published by 2004 .

\subsection{Interpretation of Sulfur Enrichment}

Low-sulfur peat or coals (sulfur content generally lower than $1.0 \mathrm{wt} \%$ ) have been found in association with terrestrial deposits [67-69]. Table 1 shows that most of the coal samples in this study had intermediate sulfur contents (1-3 wt \%). The pyrite occurring in the coal samples was fine and framboidal, associated with small veins, and primarily occurred in the coal matrix, especially in 
huminite, and lacked fracture/cleat infilling pyrite crystals (Figure 9), indicating that it was likely syngeneic and formed from the period of peat accumulation to the diagenesis stage.

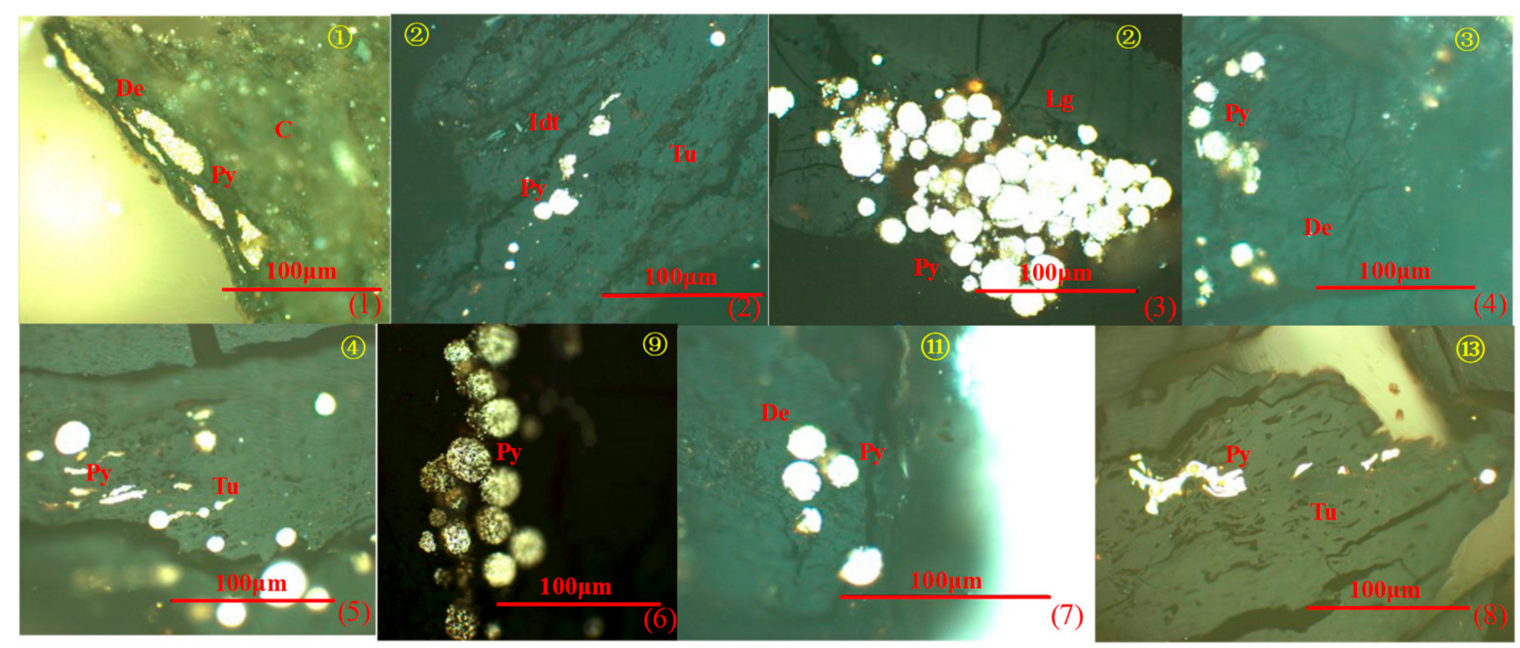

Figure 9. Occurrence of pyrite in different coal samples (the number in the yellow circle is the sample number, and the number in the red parenthesis is a series number of the photo; (1) vein pyrite, filled in desinite (De) surrounded by clay; (2) framboidal pyrite, distributed in texto-ulminite (Tu); (3) framboidal pyrite, distributed in groups around levigelinite (Lg) and texto-ulminite (Tu); (4) framboidal pyrite, distributed in desinite (De); (5) framboidal and vein pyrites distributed in texto-ulminite (Tu); (6) framboidal pyrite, distributed in groups in texto-ulminite ( $\mathrm{Tu})$; (7) framboidal pyrite, distributed in desinite (De); and (8) xenomorphic pyrite, filled in the cell of texto-ulminite (Tu)).

Figure 10 shows that the differences between organic $\delta^{34} S$ and pyritic $\delta^{34} S$ had large variations by comparing data from China, USA, Australia, and Japan [70-77]. Organic $\delta^{34} \mathrm{~S}$ in 70 sets of data from the total 116 data, including the three investigated coals, were higher than pyritic $\delta^{34} \mathrm{~S}$, and 48 sets of data were the opposite, with the remaining one being equal (Figure 10). Several researchers have stated that pyrite has lower $\delta^{34} \mathrm{~S}$ values as a result of isotopic fractionation accompanying microbial sulfate reduction $[67,69]$. Namely, syngeneic pyritic $\delta^{34} S$ values should be lower or equal to those of syngeneic organic sulfur. This finding further verified that the pyrite in the studied coal was probably syngeneic and formed through microbial sulfate reduction. In addition, the contrasting highly-variable pyritic $\delta^{34} S$ values implied that there were probably several generations of pyrite formation during the different stages of coal formation due to the possibly inhomogeneous distribution of sulfate-reducing bacteria (Figure 10) [78].

The sulfur content depends on the availability of sulfur and ferric iron, along with the activity of sulfate-reducing bacteria. Possibly, the abundance of sulfur was associated with a marine setting because of the increased source availability of sulfate ions [64,76,79-83]. However, sedimentary analyses indicated that the studied coal-bearing strata and overlying strata were deposited in terrestrial settings $[29,30,84]$. Several studies have reported that the sulfur origin of coals containing medium to high sulfur content could be derived from sulfate- and sulfide-rich source rocks via uplift and erosion and later transported to the mire through surface- and groundwater during peat growth in continental basins [85-87]. In addition, a high total sulfur content and an abundance of syngenetic pyrite crystals were also reported in coal seams within continental basins where palaeomires were fed by sulfate-rich groundwater [18,20,57,87-90]. Furthermore, leached waters from tuff layers and volcanic rocks in adjacent areas, and S-rich epigenetic hydrothermal solutions into coal seams, could elevate the sulfur contents of coals $[19,91,92]$. The leached surface waters from tuff and volcanic rocks in the studied coal based on the geologic conditions seems more possible as the studied half-graben depression is close to the east Great Xin'an Range belt with extensively developed volcanic, tuff, igneous rock, 
and marine sediment, which is enriched with $\mathrm{S}, \mathrm{Fe}$, and other elements and minerals [93,94]. If so, water from the adjacent orogenic belt flowing into peat would supply abundant detrital or mineral materials and, thus, high ash yield coal layers would be present [95]. Accordingly, the sulfur content should theoretically be positively related to the ash yield. However, Figure 11 presents an opposite relationship, which does not support a source from surface or groundwater. Moreover, the pyritic $\delta^{34} \mathrm{~S}$ enrichment $(7.5-37.5 \%$ o $)$ and high $\delta^{34} S$ ratio of pyritic sulfur to organic sulfur may have occurred from the fluvial-lacustrine or groundwater systems when compared to those in the original peat mire $[67,96]$. In addition, most of coals influenced by the marine environment are characterized by the higher organic $\delta^{34} S$ than pyritic $\delta^{34} S[71,72,75-77]$.Consequently, The lower pyritic $\delta^{34} S$ values in the studied coal possibly indicated that it was not mainly caused by fluvial-lacustrine or groundwater systems, but had a marine influence (Figure 10).

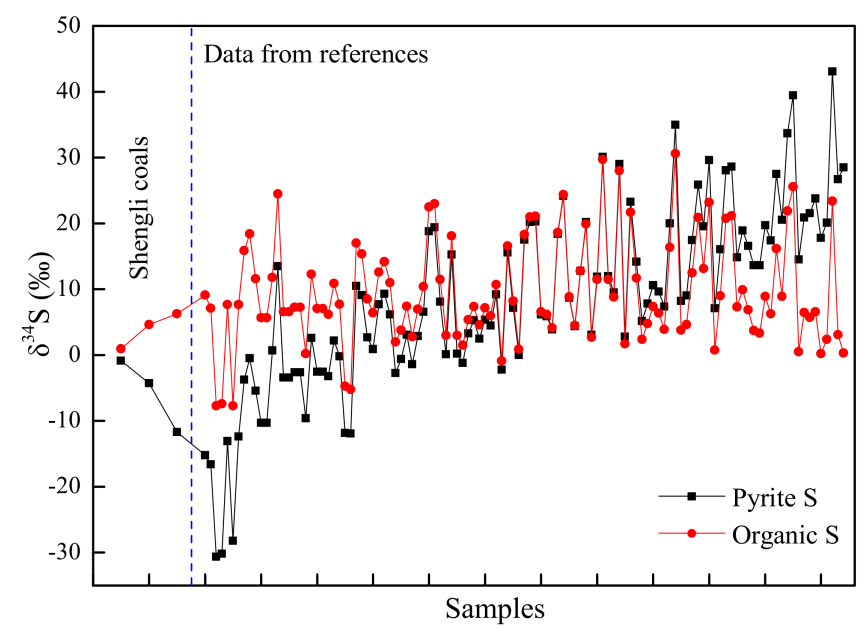

Figure 10. Comparison of isotopic composition of organic and pyritic sulfur.

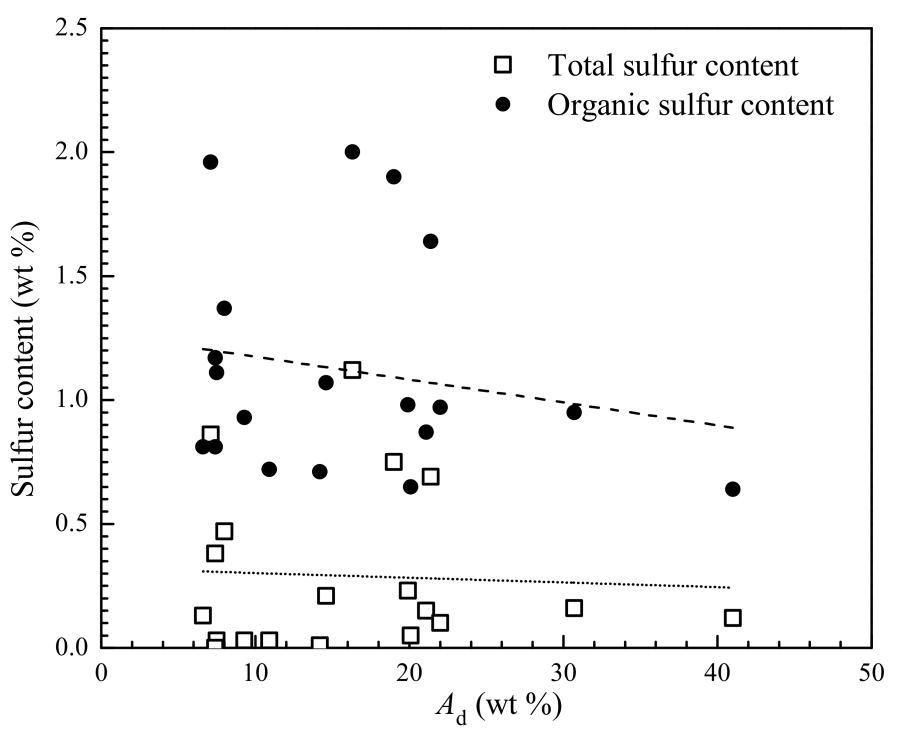

Figure 11. Relation between $A_{\mathrm{d}}$ and sulfur content.

Alternatively, one of the major sources of sulfur in the studied coal could have been from marine incursion. Geochemical indices have been generally used to characterize the influence of marine incursions on coal formation, including $\mathrm{K}, \mathrm{Mg}, \mathrm{B}, \mathrm{Mg} / \mathrm{Ca}$, $\mathrm{Sr} / \mathrm{Ba}, \mathrm{SiO}_{2}+\mathrm{Al}_{2} \mathrm{O}_{3}$, and $\mathrm{Fe}_{2} \mathrm{O}_{3}+\mathrm{CaO}+\mathrm{Mg}$. Accordingly, the geochemistry composition of the studied coal was further examined by XRF. Figure 12 shows that some coal layers have high contents of $\mathrm{K}, \mathrm{Mg}, \mathrm{Sr}, \mathrm{CaO}[63,64], \mathrm{Sr} / \mathrm{Ba}$ 
(>the average of world coals (0.67) [65], and high $\mathrm{Fe}_{2} \mathrm{O}_{3}+\mathrm{CaO}+\mathrm{MgO}(>20 \%)$ but relatively low $\mathrm{SiO}_{2}+\mathrm{Al}_{2} \mathrm{O}_{3}(<75 \%)$ [66], indicating that some of the coal layers in the studied area were formed in marine or brackish environments and the swamp had undergone marine incursions several times. Additionally, the strong bacterial activities inferred above also indicate a neutral to alkaline environment, namely, a marine- or brackish- water environment [95]. The salinity tolerance studies of identified sporopollen assemblages including Cyathidites, Cicatricosisporites, Classopollis, and Leiotriletes, well developed in the studied coal seam, which were adapted to an environment of fresh water to brackish water environment $[97,98]$. Furthermore, the huminite content and ratio of huminite to inertinite, which are positively related to the water base level of the peat, fit with the sulfur content (Figure 13). Specifically, the water base level rise fits with possible marine incursions during peat accumulation. This matching relationship also supports the marine incursions. Additionally, the brackish-water Parabohaidina-Fromea-Nyktericysta-Vesperopsis dinocyst assemblage, conchostracans, ostracods, gastropods, and fish were found in the Saihantala Formation in the Erlian Basin [99]. As has been widely reported, the Songliao Basin in the east of the studied basin at the same geologic time underwent several marine incursions [100]. However, further investigations for robust evidence and the conduit for the lake-marine connection are needed for a better understanding.

Sulfate brought in by marine and/or sulfate-rich groundwater might have played a key role in the origins of sulfur in coal and is believed to be geochemically stable; thus, sulfate is bacterially reduced to form $\mathrm{H}_{2} \mathrm{~S}[69,101]$. The hydrogen sulfide thus generated may react with iron to form iron sulfide species and with organic matter to form organosulfur constituents [83]. Accordingly, specific $\mathrm{pH}$ and anaerobic conditions required by sulfate-reducing bacteria are very important to $\mathrm{H}_{2} \mathrm{~S}$ generation, thus enhancing the sulfur content [69]. Figures 14 and 15 show that the organic and pyritic sulfur contents were positively related to the huminite content and GI and negatively related to the inertinite content. The high huminite content and GI, but low telohuminite content, indicated the reducing and alkalescent environment which was suited for bacterial sulfate reduction and $\mathrm{H}_{2} \mathrm{~S}$. Thus, more sulfur was subsequently fixed in coal [102]. Microscopic analysis further verified that most of the pyrite occurred in association with huminite (Figure 9). Conversely, the high inertinite represents an aerobic environment that is not appropriate for fixed sulfur in coal (Figure 16).

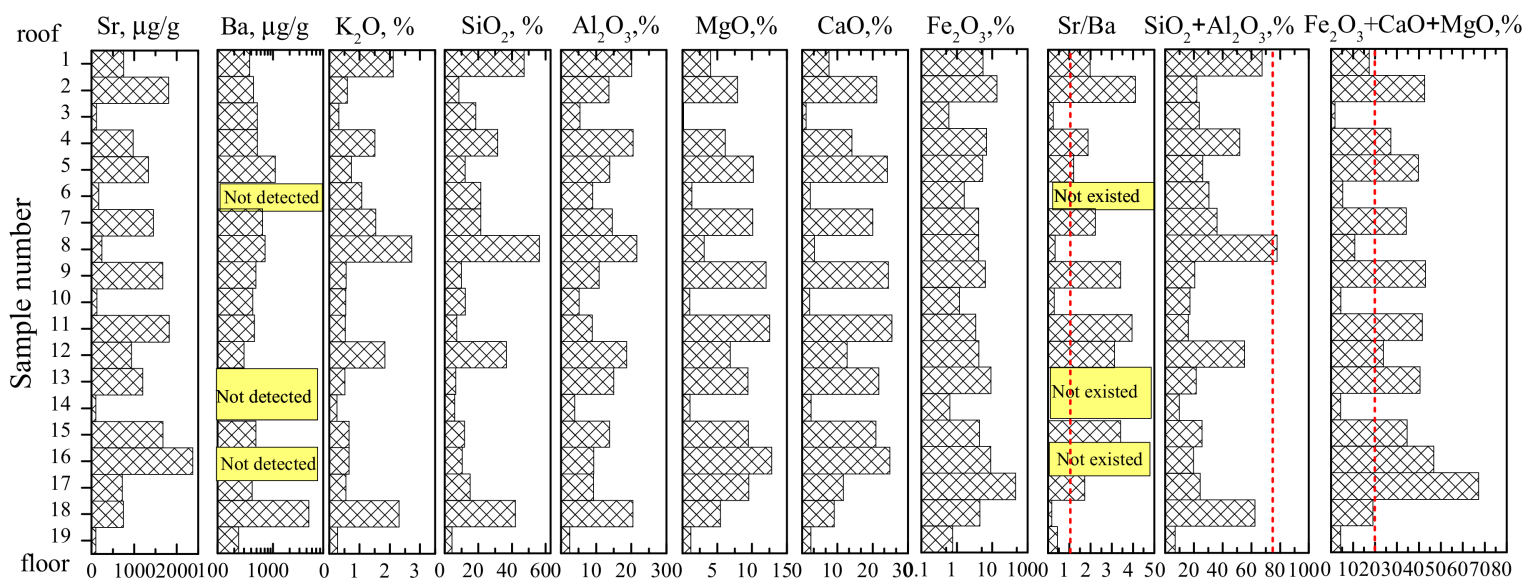

Figure 12. Variations of partial chemical compositions of the coal ash. 


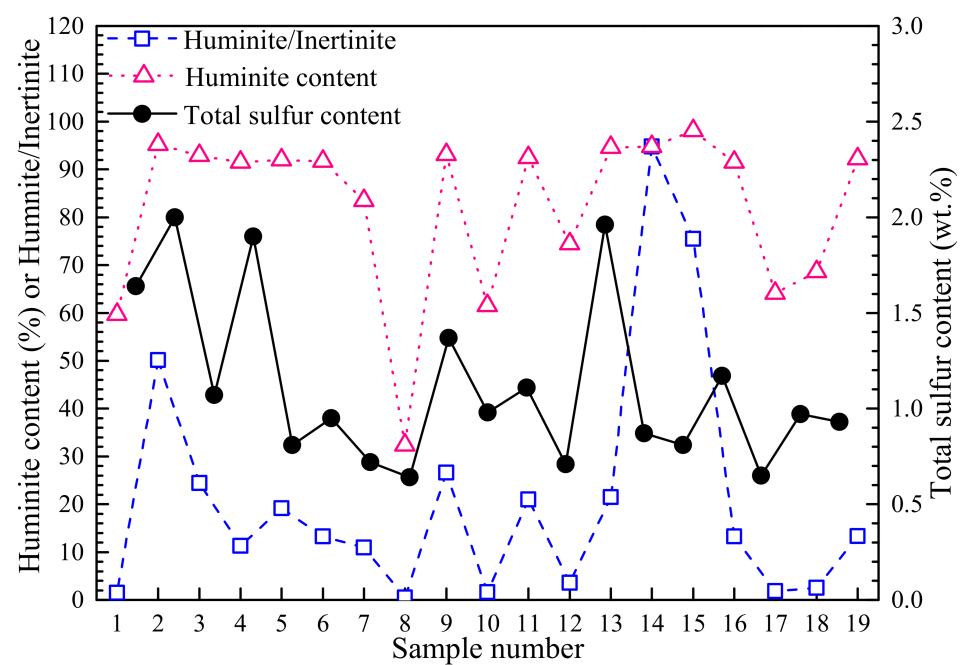

Figure 13. Matching relation between huminite and sulfur contents.

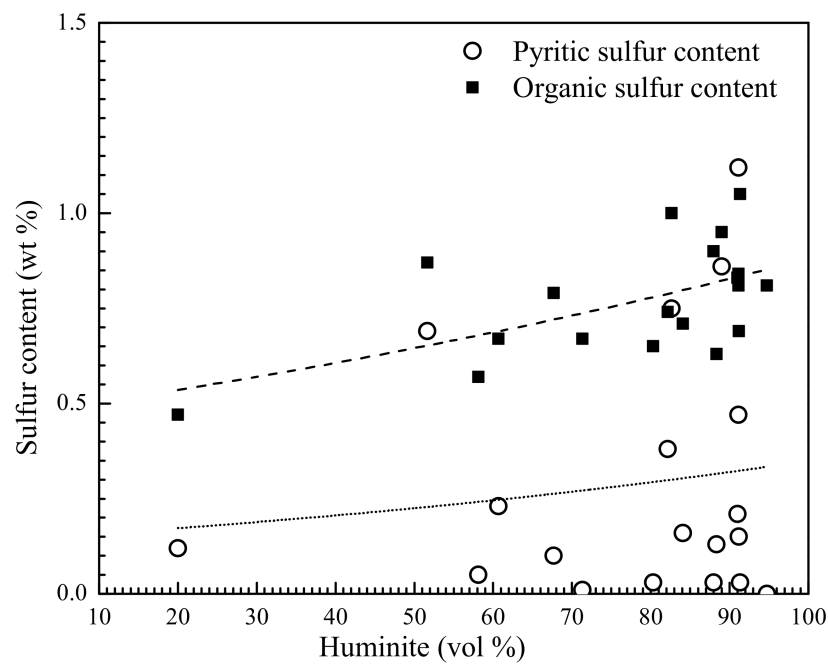

Figure 14. Relationship between huminite and sulfur contents.

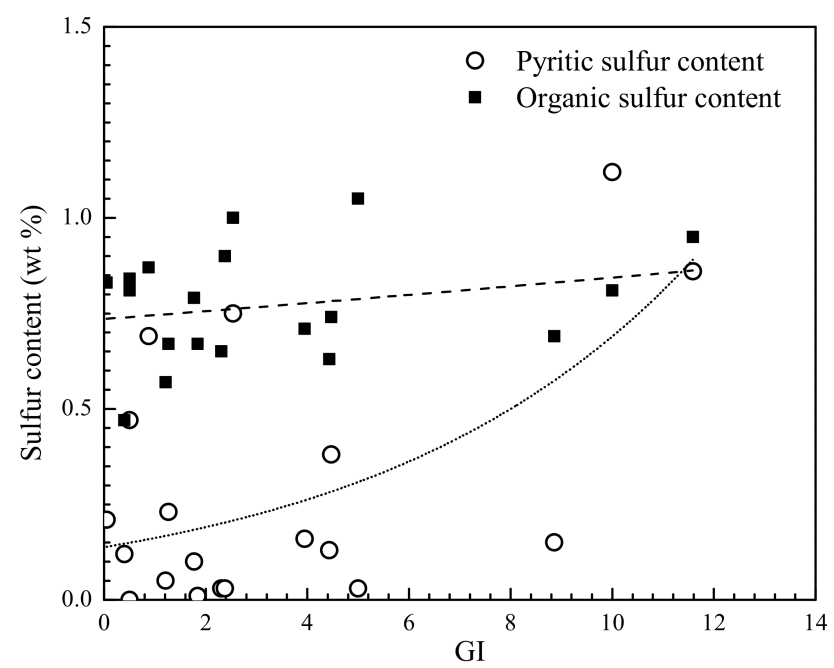

Figure 15. Relationship between GI and sulfur contents. 


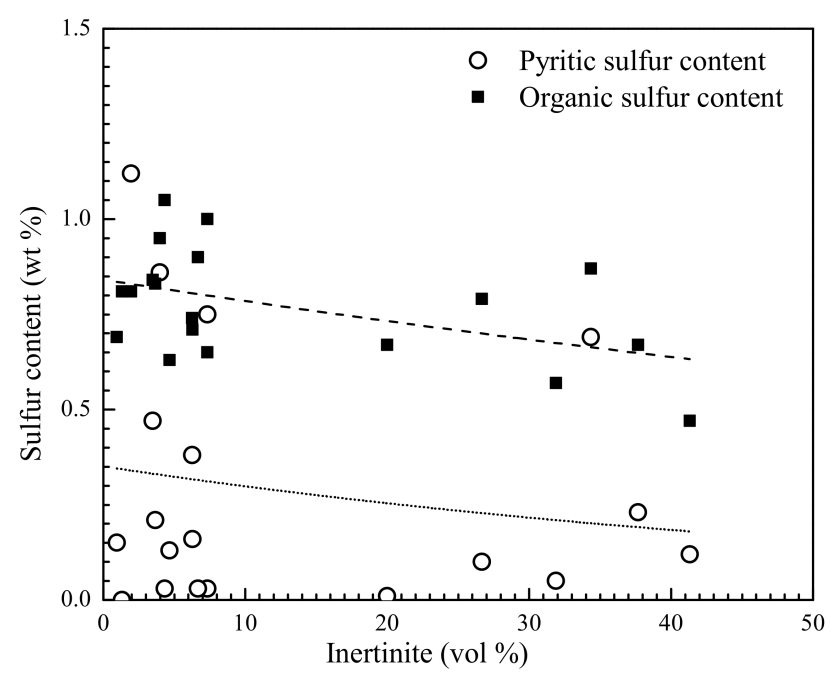

Figure 16. Relationship between inertinite and sulfur contents.

\subsection{Vertical Evolution of Climate and Coal Deposition}

\subsubsection{Vertical Evolution of Climate}

Spore-pollen assemblages have been widely adopted to track climate as each climate has a typical plant community regardless of the past or present [24,103-105]. Consequently, the paleoclimate can be deduced by palynology studies. The main spore-pollen assemblages of the studied No. 5 coal seam, which had good response for climate and its abundance (\%) was higher than $10 \%$, were selected. Table 5 shows the warm climate signals accounting for $13.42 \%, 42.86 \%, 46.67 \%, 44.44 \%, 10.53 \%, 72.22 \%$, and $42.11 \%$ within samples $3,5,8,10,12,17$, and 18 , respectively, while hot climate signals accounted for $14.29 \%, 13.16 \%$, and $15.79 \%$ within samples 5,12 , and 18 , respectively $[24,106,107]$. Therefore, warm climate signals were dominant in most of the samples, while some samples were dominated by a hot climate signal. A conclusion can be made that the No. 5 coal seam formed in warm to hot, and wet, climatic conditions with intermittent dry periods, indicating a subtropical climate. The palynology research further confirmed that the climate was categorized into the paratropical zone during the geological period made by former researchers $[44,45]$.

Table 5. Main spore-pollen constituents (>10\%) and climate signal (climate signal cited from [24,106,107]).

\begin{tabular}{|c|c|c|c|c|c|c|c|c|}
\hline \multirow{2}{*}{ Spore-Pollen Category } & \multicolumn{7}{|c|}{ Number of the Sample } & \multirow{2}{*}{ Climate Signal } \\
\hline & 3 & 5 & 8 & 10 & 12 & 17 & 18 & \\
\hline Leiotriletes sp. & 12.08 & & & & & & & Warm and Wet \\
\hline Cyathidites minor & 13.42 & & 30.48 & 20.63 & & 11.11 & 10.53 & Warm and wet \\
\hline Laevigatosporites ovatus & & 14.29 & & & & & & Hot and wet \\
\hline Cycadopites sp. & & & & & 13.16 & & & Hot and wet \\
\hline Classopollis annulatus & & & & & & & 15.79 & Hot and dry \\
\hline Pinuspollenites spp. & & 21.43 & 16.19 & 23.81 & & 33.33 & 21.05 & Warm and semiarid \\
\hline Piceaepollenites spp & & 21.43 & & & 10.53 & 27.78 & 10.53 & Warm and semiarid \\
\hline $\begin{array}{l}\text { Unidentified non-rib } \\
\text { bisaccate pollen }\end{array}$ & & & & & 23.68 & 11.11 & 26.32 & Unknown \\
\hline
\end{tabular}

The vertical variations of $\delta^{13} \mathrm{C}$ profiles of the 19 coal samples are given in Figure 17. The reasons for those variations might be changes in plant types, the direct temperature-dependent fractionation process, or indirect temperature changes due to variations in atmospheric $\mathrm{CO}_{2}$, humidity, and precipitation [108-113]. It was verified that the $\delta^{13} \mathrm{C}$ values had differed by $2.6-4.5 \%$ ootween angiosperms and gymnosperms $[112,114]$. However, the $\delta^{13} \mathrm{C}$ was from gymnosperm and fern instead 
of angiosperm in the studied coal. The average $\delta^{13} \mathrm{C}$ value of the samples $3,5,8$, and 10 dominated by ferns was about $-22.34 \%$, while that from samples 12,17 , and 18 dominated by gymnosperms was about $-22.66 \%$. This finding indicated that the fern cycle was increased in the upper coal seam, but the greater enrichment (positive) in the top cycle could also be due to changing temperature. Furthermore, several decreasing profiles were still obvious, even though they were observed from dominant gymnosperms in the lower part of the coal or from ferns in the upper part. It has been reported that temperature was clearly positively related to the $\delta^{13} \mathrm{C}$ value extracted from wood, although there were some differences on the $\delta^{13} \mathrm{C}$ value increment per degree centigrade $[108,109]$. The air temperature, as reflected by carbon isotopes in brown coal, also showed that an overall decline of carbon isotope values within the Garzweiler coal seam possibly indicated a general cooling trend of $2{ }^{\circ} \mathrm{C}$ in the late Middle Miocene, which was in accordance with a cooling event recorded in the marine $\delta^{18} \mathrm{O}$ data [115]. Therefore, the temperature might be an important factor controlling vertical variations of the $\delta^{13} \mathrm{C}$ values. Accordingly, the lowest $\left(+0.18 \%{ }^{13} \mathrm{C} /{ }^{\circ} \mathrm{C}\right)$ and highest $\left(+0.39 \%{ }^{13} \mathrm{C} /{ }^{\circ} \mathrm{C}\right) \delta^{13} \mathrm{C}$ value increments with temperature reported by the references were adopted to infer air temperature changes during peat accumulation $[108,111]$. The temperature alternation calculated by these two extreme values showed that the minimum temperature variation ranged from $-2.68^{\circ} \mathrm{C}$ to $2.12{ }^{\circ} \mathrm{C}$, and the maximum variation ranged from $-4.92{ }^{\circ} \mathrm{C}$ to $3.89^{\circ} \mathrm{C}$ (Figure $17 \mathrm{c}$ ). Accordingly, three periods of cooling-warming trends were identified during the peat accumulation. However, as mentioned above, temperature was likely one of factors affecting the $\delta^{13} \mathrm{C}$ variations. Therefore, other temperature indicators, such as those recorded in marine $\delta^{18} \mathrm{O}$ data, seem to be necessary for a detailed comparison and validation of the cooling-warming cycles of climate.

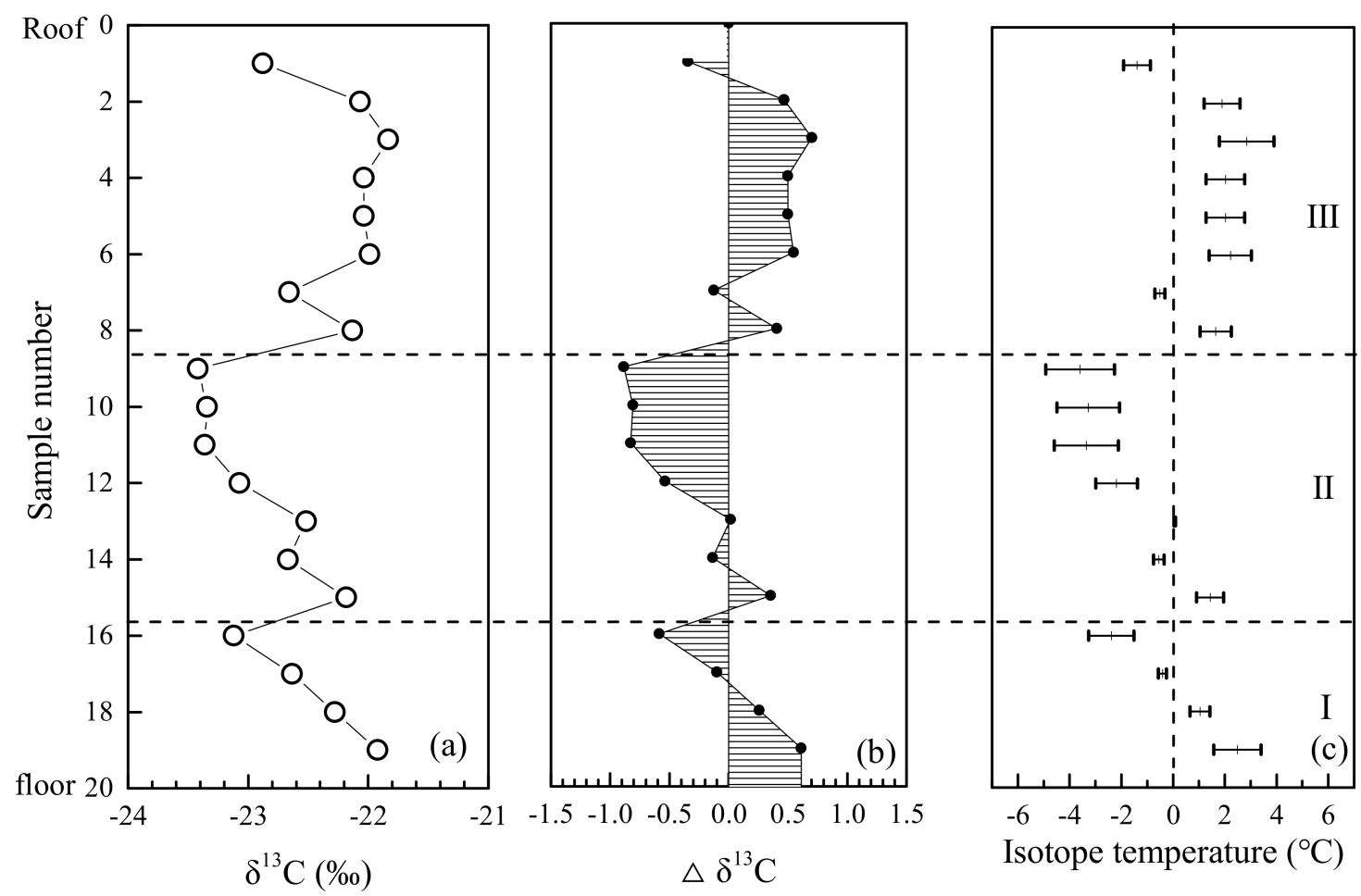

Figure 17. (a) Vertical carbon isotope record of lignite (\%o vs. PDB); (b) normalized record (line) $\Delta \delta^{13} \mathrm{C}$ given as $\delta^{13} \mathrm{C}$ minus the average value of the entire coal seam; and $(\mathrm{c})+0.39 \%{ }^{13} \mathrm{C} /{ }^{\circ} \mathrm{C}$ was adopted in the lowest temperature change calculation obtained by [108] and $+0.18 \%{ }^{13} \mathrm{C} /{ }^{\circ} \mathrm{C}$ used in highest temperature changes found by [111]. 


\subsubsection{Vertical Evolution of the Peat Environment}

Figure 18 shows that the No. 5 coal seam displays three general cycles from the bottom to the roof based on the sharp changes observed in the variations of huminite, inertinite, and mineral contents, the ratio of huminite to inertinite $(\mathrm{H} / \mathrm{I})$, and the TPI and GI values, which corresponded well to Figure 17, although there might be sub-cycles within the general trend. A higher huminite content, $\mathrm{H} / \mathrm{I}$ and GI reflected a stronger degree of gelification, while higher inertinite content inferred a "drier" and more oxidized environment. Therefore, the bottom cycle was deposited in a wetting-drying-wetting condition, and the upper two cycles were deposited in drying-upwards conditions. These cycles were similar to those obtained in the Australian and German Cenozoic brown coals [116]. These vertical cycles during peat accumulation were likely caused by climate change as the relatively high inertinite contents in layers $1,8,17$, and 18, which corresponded well to the high percentages of vegetation grown in semiarid to dry environments inferred from palynology.

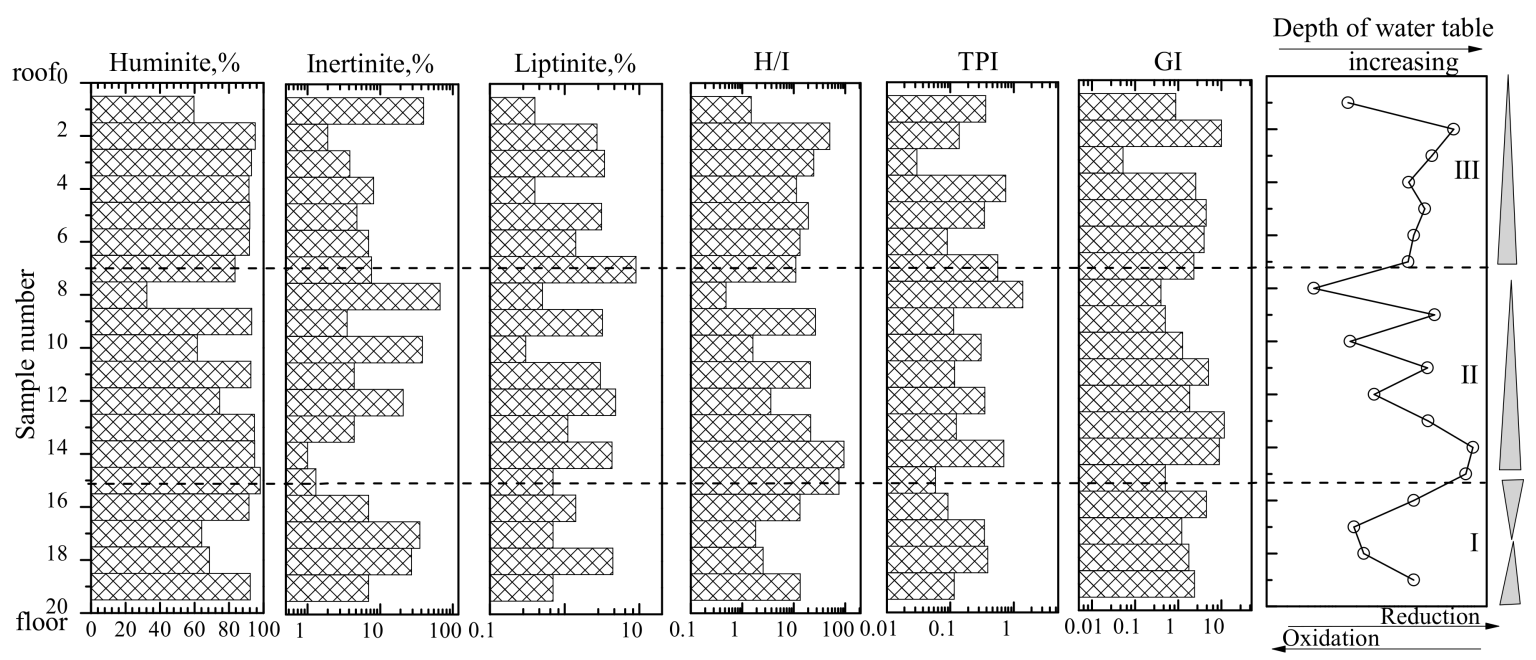

Figure 18. Vertical variations of the indices of the maceral and coal facies of the No. 5 coal seam.

\section{Conclusions}

The thickness of the No. 5 coal seam in the Shengli coalfield reached $16.8 \mathrm{~m}$. The mean

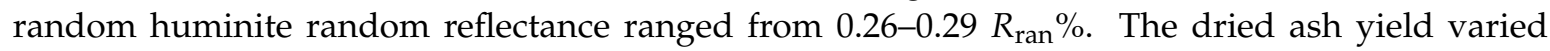
from $6.59-41.00 \mathrm{wt} \%$. The total sulfur content ranged from $0.64-2.00 \mathrm{wt} \%$, and the sulfur was primarily pyritic and organic sulfur. The $\delta^{13} \mathrm{C}$ varied from -23.42 to $-21.83 \%$. The peat-forming vegetation consisted of herbaceous and shrub helophytes that grew in a subtropical climate characterized by warm and wet climatic conditions with intermittent dry conditions. The total sulfur content was positively related to the huminite content and negatively related to the inertinite content. We proposed that intermediate sulfur content in the studied coal seam originated via bacterial action with sulfur from marine incursions. Three periods of overall cooling-warming successions were identified by temperature-related precursors of organic carbon isotopes occurring in the peat accumulation. During peat accumulation, the water table underwent three cycles where the level of the water table decreased and then increased followed by two upper decreasing-increasing trends. These cycles in the peat-accumulation environment are likely to be attributable to climate change.

Altogether this study produced results that contribute to our knowledge of the autochthonous genesis, possibility of marine incursion, vertical variations of climate, and the depositional environment of the thick coal seam of Saihantala Formation in the later early Cretaceous. The general deposition of the coal seams fit into the existing widely-accepted sequence stratigraphic model of the Basin, except for the possibility of the marine incursion during peat accumulation. These results are helpful for increasing the understanding of the detailed formation process of a single coal seam, not just 
a sedimentary event, and also potentially applicable to the evaluation of coalbed methane exploration and evaluation. However, the studied data were just from one coal section and sampling points were also limited, thus, some assumptions had to be made for the deduction of climate and environment. As a result, more careful field investigations, experiments, and analysis should be performed on the regional correlation of the coal layer, marine incursion channel, and the factors that caused the incursions, reliable paleo-environmental indicators for coal seams, and regionally-vertical variation patterns of the depositional environment of the coal seam, and their controlling factor.

Acknowledgments: Financial supports are from the National Natural Science Foundation of China (41672149, 41530314), the Top Discipline Construction Funds of China University of Mining and Technology, and the Fundamental Research Funds for the Central Universities (2012QNB32, 2015XKZD07) are gratefully acknowledged.

Author Contributions: Jian Shen, Yong Qin and Yulin Shen conceived and designed the experiments and collected the samples; Jinyue Wang performed the experiments; Jian Shen and Jinyue Wang analyzed the data; Jian Shen, Yong Qin and Geoff Wang wrote the paper.

Conflicts of Interest: The authors declare no conflict of interest. The founding sponsors had no role in the design of the study; in the collection, analyses, or interpretation of data; in the writing of the manuscript, and in the decision to publish the results.

\section{References}

1. Cheng, A.; Cao, D.; Yuan, T.; Shao, L.; Song, H.; Tang, Y.; Ning, S.; Ma, S.; Zhang, G.; Wang, J. Evaluation of Coal Resource in China; China National Administration of Coal Geology: Beijing, China, 2013; p. 728.

2. Dai, S.; Hou, X.; Ren, D.; Tang, Y. Surface Analysis of Pyrite in the No. 9 Coal Seam, Wuda Coalfield, Inner Mongolia, China, Using High-resolution Time-of-flight Secondary Ion Mass-spectrometry. Int. J. Coal Geol. 2003, 55, 139-150. [CrossRef]

3. Teichmüller, M. The genesis of coal from the viewpoint of coal petrology. Int. J. Coal Geol. 1989, 12, 1-87. [CrossRef]

4. Marchioni, D. Petrography and Depositional Environment of the Liddell Seam, Upper Hunter Valley, New South Wales. Int. J. Coal Geol. 1980, 1, 35-61. [CrossRef]

5. Diessel, C. On the Correlation between Coal Facies and Depositional Environments. In Proceedings of the 20th Newcastle Symposium on "Advances in the Study of the Sydney Basin"; Department of Geology, University of Newcastle: Newcastle, Australia, 1986; pp. 19-22.

6. Diessel, C.F. Coal-Bearing Depositional Systems; Springer Science \& Business Media: New Delhi, India, 2012; pp. 1-579.

7. Calder, J.H.; Gibling, M.R.; Mukhopadhyay, P.K. Peat Formation in a Westphalian B Piedmont Setting, Cumberland Basin, Nova Scotia: Implications for the Maceral-based Interpretation of Rheotrophic and Raised Paleomires. Bull. Soc. Géol. Fr. 1991, 162, 283-298.

8. Kalkreuth, W.; Kotis, T.; Papanicolaou, C.; Kokkinakis, P. The Geology and Coal Petrology of a Miocene Lignite Profile at Meliadi Mine, Katerini, Greece. Int. J. Coal Geol. 1991, 17, 51-67. [CrossRef]

9. Kalaitzidis, S.; Bouzinos, A.; Papazisimou, S.; Christanis, K. A Short-Term Establishment of Forest Fen Habitat during Pliocene Lignite Formation in the Ptolemais Basin, Nw Macedonia, Greece. Int. J. Coal Geol. 2004, 57, 243-263. [CrossRef]

10. Staub, J.R. Marine Flooding Events and Coal Bed Sequence Architecture in Southern West Virginia. Int. J. Coal Geol. 2002, 49, 123-145. [CrossRef]

11. Petersen, H.I.; Ratanasthien, B. Coal Facies in a Cenozoic Paralic Lignite Bed, Krabi Basin, Southern Thailand: Changing Peat-Forming Conditions Related to Relative Sea-Level Controlled Watertable Variations. Int. J. Coal Geol. 2011, 87, 2-12. [CrossRef]

12. Crosdale, P.J. Coal Maceral Ratios as Indicators of Environment of Deposition: Do They Work for Ombrogenous Mires? An Example from the Miocene of New Zealand. Org. Geochem. 1993, 20, 797-809. [CrossRef]

13. Moore, T.A.; Shearer, J.C. Peat/Coal Type and Depositional Environment-Are They Related? Int. J. Coal Geol. 2003, 56, 233-252. [CrossRef]

14. Scott, A.C. Coal Petrology and the Origin of Coal Macerals: A Way Ahead? Int. J. Coal Geol. 2002, 50, 119-134. [CrossRef] 
15. Wüst, R.A.J.; Hawke, M.I.; Marc Bustin, R. Comparing Maceral Ratios from Tropical Peatlands with Assumptions from Coal Studies: Do Classic Coal Petrographic Interpretation Methods Have to Be Discarded? Int. J. Coal Geol. 2001, 48, 115-132. [CrossRef]

16. Çelik, Y.; Karayiğit, A.İ.; Querol, X.; Oskay, R.G.; Mastalerz, M.; Kayseri Özer, M.S. Coal Characteristics, Palynology, and Palaeoenvironmental Interpretation of the Yeniköy Coal of Late Oligocene Age in the Thrace Basin (NW Turkey). Int. J. Coal Geol. 2017, 181, 103-123. [CrossRef]

17. Jasper, K.; Hartkopf-Fröder, C.; Flajs, G.; Littke, R. Evolution of Pennsylvanian (Late Carboniferous) Peat Swamps of the Ruhr Basin, Germany: Comparison of Palynological, Coal Petrographical and Organic Geochemical Data. Int. J. Coal Geol. 2010, 83, 346-365. [CrossRef]

18. Karayiğit, A.I.; Oskay, R.G.; Christanis, K.; Tunoğlu, C.; Tuncer, A.; Bulut, Y. Palaeoenvironmental Reconstruction of the Çardak Coal Seam, SW Turkey. Int. J. Coal Geol. 2015, 139, 3-16. [CrossRef]

19. Karayiğit, A.I.; Bircan, C.; Mastalerz, M.; Oskay, R.G.; Querol, X.; Lieberman, N.R.; Türkmen, I. Coal Characteristics, Elemental Composition and Modes of Occurrence of Some Elements in the Isaalan Coal (Balikesir, NW Turkey). Int. J. Coal Geol. 2017, 172, 43-59. [CrossRef]

20. Karayiğit, A.I.; Littke, R.; Querol, X.; Jones, T.; Oskay, R.G.; Christanis, K. The Miocene Coal Seams in the Soma Basin (W Turkey): Insights from Coal Petrography, Mineralogy and Geochemistry. Int. J. Coal Geol. 2017, 173, 110-128. [CrossRef]

21. Mitrović, D.; Đoković, N.; Životić, D.; Bechtel, A.; Šajnović, A.; Stojanović, K. Petrographical and Organic Geochemical Study of the Kovin Lignite Deposit, Serbia. Int. J. Coal Geol. 2016, 168, 80-107. [CrossRef]

22. Zdravkov, A.; Bechtel, A.; Sachsenhofer, R.F.; Kortenski, J.; Gratzer, R. Vegetation Differences and Diagenetic Changes between Two Bulgarian Lignite Deposits-Insights from Coal Petrology and Biomarker Composition. Org. Geochem. 2011, 42, 237-254. [CrossRef]

23. Saiki, K.I.; Wang, Y.-D. Preliminary Analysis of Climate Indicator Plant Distribution in the Early Cretaceous of China. J. Asian Earth Sci. 2003, 21, 813-822. [CrossRef]

24. Zhang, M.; Dai, S.; Heimhofer, U.; Wu, M.; Wang, Z.; Pan, B. Palynological Records from Two Cores in the Gongpoquan Basin, Central East Asia: Evidence for Floristic and Climatic Change during the Late Jurassic to Early Cretaceous. Rev. Palaeobot. Palynol. 2014, 204, 1-17. [CrossRef]

25. Eble, C.F.; Grady, W.C.; Blake, B.M. Dunkard Group Coal Beds: Palynology, Coal Petrography and Geochemistry. Int. J. Coal Geol. 2013, 119, 32-40. [CrossRef]

26. Caratini, C.; Tissot, C. Paleogeographical Evolution of the Mahakam Delta in Kalimantan, Indonesia during the Quaternary and Late Pliocene. Rev. Palaeobot. Palynol. 1988, 55, 217-228. [CrossRef]

27. Na, Y.; Manchester, S.R.; Sun, C.; Zhang, S. The Middle Jurassic Palynology of the Daohugou Area, Inner Mongolia, China, and Its Implications for Palaeobiology and Palaeogeography. Palynology 2015, 39, 270-287. [CrossRef]

28. Dai, S.; Wang, X.; Seredin, V.V.; Hower, J.C.; Ward, C.R.; O’Keefe, J.M.K.; Huang, W.; Li, T.; Li, X.; Liu, H.; et al. Petrology, Mineralogy, and Geochemistry of the Ge-Rich Coal From The Wulantuga Ge Ore Deposit, Inner Mongolia, China: New Data and Genetic Implications. Int. J. Coal Geol. 2012, 90-91, 72-99. [CrossRef]

29. Wang, S.; Shao, L.; Sun, Q.; Wang, D.; Lu, J.; Sun, B. Sequence and Coal Accumulation of the Lower Cretaceous Saihantala Formation in Jiergalangtu Sag of Erlian Basin. J. Palaeogeogr. 2015, 17, 393-404, (In Chinese with English Abstract).

30. Wu, X.; Wu, C.; Mao, X.; Zhang, J. Analysis on Sedimentary Characteristics and Allochthonous Genesis of Extra-Thick Seam Jin Jiergalangtu Depression, Saihantala Formation. Acta Sedimentol. Sin. 2016, 34, 1155-1164, (In Chinese with English Abstract).

31. Lin, C.; Kenneth, E.; Li, S.; Wan, Y.; Ren, J.; Zhang, Y. Sequence Architecture, Depositional systems, and Controls on Development of Lacustrine Basin Fills in Part of the Erlian Basin, Northeast China. AAPG Bull. 2001, 85, 2017-2043.

32. Zhang, W. Sedimentary Facies and Hydrocarbon-bearing of Lower Cretaceous Strata in Erlian Basin. Sci. Geol. Sin. 1998, 33, 204-213, (In Chinese with English Abstract).

33. Zhuang, X.; Querol, X.; Alastuey, A.; Juan, R.; Plana, F.; Lopez-Soler, A.; Du, G.; Martynov, V.V. Geochemistry and Mineralogy of the Cretaceous Wulantuga High-Germanium Coal Deposit in Shengli Coal Field, Inner Mongolia, Northeastern China. Int. J. Coal Geol. 2006, 66, 119-136. [CrossRef]

34. Qi, H.; Hu, R.; Zhang, Q. Ree Geochemistry of the Cretaceous Lignite from Wulantuga Germanium Deposit, Inner Mongolia, Northeastern China. Int. J. Coal Geol. 2007, 71, 329-344. [CrossRef] 
35. Qi, H.; Hu, R.; Zhang, Q. Concentration and Distribution of Trace Elements in Lignite from the Shengli Coalfield, Inner Mongolia, China: Implications on Origin of the Associated Wulantuga Germanium Deposit. Int. J. Coal Geol 2007, 71, 129-152. [CrossRef]

36. Du, G.; Zhuang, X.; Querol, X.; Izquierdo, M.; Alastuey, A.; Moreno, T.; Font, O. Ge Distribution in the Wulantuga High-Germanium Coal Deposit In The Shengli Coalfield, Inner Mongolia, Northeastern China. Int. J. Coal Geol. 2009, 78, 16-26. [CrossRef]

37. Dai, S.; Liu, J.; Ward, C.R.; Hower, J.C.; Xie, P.; Jiang, Y.; Hood, M.M.; O'Keefe, J.M.K.; Song, H. Petrological, Geochemical, and Mineralogical Compositions of the Low-Ge Coals from the Shengli Coalfield, China: A Comparative Study with Ge-Rich Coals and a Formation Model for Coal-Hosted Ge Ore Deposit. Ore Geol. Rev. 2015, 71, 318-349. [CrossRef]

38. Dai, S.; Yan, X.; Ward, C.R.; Hower, J.C.; Zhao, L.; Wang, X.; Zhao, L.; Ren, D.; Finkelman, R.B. Valuable Elements in Chinese Coals: A Review. Int. Geol. Rev. 2016, 1-31. [CrossRef]

39. Kolker, A.; Scott, C.; Hower, J.C.; Vazquez, J.A.; Lopano, C.L.; Dai, S. Distribution of Rare Earth Elements in Coal Combustion Fly Ash, Determined by Shrimp-Rg Ion Microprobe. Int. J. Coal Geol. 2017, 184, 1-10. [CrossRef]

40. Dai, S.; Finkelman, R.B. Coal as a Promising Source of Critical Elements: Progress and Future Prospects. Int. J. Coal Geol. 2018, 186, 155-164. [CrossRef]

41. Seredin, V.V.; Dai, S. Coal Deposits as Potential Alternative Sources for Lanthanides and Yttrium. Int. J. Coal Geol. 2012, 94, 67-93. [CrossRef]

42. Hower, J.C.; Granite, E.J.; Mayfield, D.B.; Lewis, A.S.; Finkelman, R.B. Notes on Contributions to the Science of Rare Earth Element Enrichment in Coal and Coal Combustion Byproducts. Minerals 2016, 6, 32. [CrossRef]

43. Hower, J.C.; Groppo, J.G.; Henke, K.R.; Hood, M.M.; Eble, C.F.; Honaker, R.Q.; Zhang, W.; Qian, D. Notes on the Potential for the Concentration of Rare Earth Elements and Yttrium in Coal Combustion Fly Ash. Minerals 2015, 5, 356-366. [CrossRef]

44. Fan, X.; Nie, F.; Chen, Y.; Wang, W. Discussion on Age and Paleo Geographical Environment of Ore Bearing Strata for Sandstone-Type Uranium Deposits in Bayanwula Area, Erlian Basin. Uranium Geol. 2008, 24, 150-154.

45. Scotese, C.R. Paleomap Project. Available online: http://www.scotese.com/ecretcli.htm (accessed on 8 February 2018).

46. Cheng, J.; Shang, Y. Early Cretaceous Palynological Assemblage Sequence and Palaeoclimate Research in Zhalainuoer Coalmine, Manzhouli, Inner Mongolia. Acta Palaeontol. Sin. 2015, 54, 316-341, (In Chinese with English Abstract).

47. Wang, D.; Shao, L.; Zhang, Q.; Ding, F.; Li, Z.; Zhang, W. Analysis of Coal-accumulating Characteristics in the Lower Cretaceous Coal-Containing Strata of the Erlian Basin Group. J. China Univ. Min. Technol. 2013, 42, 257-265, (In Chinese with English Abstract).

48. Bonnetti, C.; Malartre, F.; Huault, V.; Cuney, M.; Bourlange, S.; Liu, X.; Peng, Y. Sedimentology, Stratigraphy and Palynological Occurrences of the Late Cretaceous Erlian Formation, Erlian Basin, Inner Mongolia, People's Republic of China. Cretac. Res. 2014, 48, 177-192. [CrossRef]

49. Wu, G.; Sun, F.; Zhao, C.; Li, Z.; Zhao, A.; Pang, Q.; Li, G. Discovery of the Early Paleozoic Post-collisional Granites in Northern Margin of the Erguna Massif and Its Geological Significance. Chin. Sci. Bull. 2005, 50, 2733-2743. [CrossRef]

50. Ying, J.; Zhou, X.; Zhang, L.; Wang, F. Geochronological Framework of Mesozoic Volcanic Rocks in the Great Xing'an Range, Ne China, and Their Geodynamic Implications. J. Asian Earth Sci. 2010, 39, 786-793. [CrossRef]

51. Graham, S.; Hendrix, M.; Johnson, C.; Badamgarav, D.; Badarch, G.; Amory, J.; Porter, M.; Barsbold, R.; Webb, L.; Hacker, B. Sedimentary Record and Tectonic Implications of Mesozoic Rifting in Southeast Mongolia. Geol. Soc. Am. Bull. 2001, 113, 1560-1579. [CrossRef]

52. Sun, B.; Shao, L.; Zhao, Q.; Li, W.; Chen, G. Evaluation of Coalbed Gas Exploration Target in Erlian Basin. Coal. Geol. Explor. 2008, 36, 22-26, (In Chinese with English Abstract).

53. Dai, S.; Ren, D.; Chou, C.-L.; Finkelman, R.B.; Seredin, V.V.; Zhou, Y. Geochemistry of Trace Elements in Chinese Coals: A Review of Abundances, Genetic Types, Impacts on Human Health, and Industrial Utilization. Int. J. Coal Geol. 2012, 94, 3-21. [CrossRef] 
54. Dai, S.; Wang, P.; Ward, C.R.; Tang, Y.; Song, X.; Jiang, J.; Hower, J.C.; Li, T.; Seredin, V.V.; Wagner, N.J.; et al. Elemental and Mineralogical Anomalies in the Coal-hosted Ge Ore Deposit of Lincang, Yunnan, Southwestern China: Key Role of $\mathrm{N}_{2}-\mathrm{CO}_{2}$-mixed Hydrothermal Solutions. Int. J. Coal Geol. 2015, 152, $19-46$. [CrossRef]

55. Li, W.; Liu, Z. The Cretaceous Palynofloras and Their Bearing on Stratigraphic Correlation in China. Cretac. Res. 1994, 15, 333-365. [CrossRef]

56. Mukhopadhyay, P.K. Organic Petrography and Organic Geochemistry of Texas Tertiary Coals in Relation to Depositional Environment and Hydrocarbon Generation; Bureau of Economic Geology: Austin, TX, USA, 1989.

57. Oskay, R.G.; Christanis, K.; Inaner, H.; Salman, M.; Taka, M. Palaeoenvironmental Reconstruction of the Eastern Part of the Karapınar-Ayrancı Coal Deposit (Central Turkey). Int. J. Coal Geol. 2016, 163, 100-111. [CrossRef]

58. Kalaitzidis, S.; Siavalas, G.; Skarpelis, N.; Araujo, C.V.; Christanis, K. Late Cretaceous Coal Overlying Karstic Bauxite Deposits in the Parnassus-Ghiona Unit, Central Greece: Coal Characteristics and Depositional Environment. Int. J. Coal Geol. 2010, 81, 211-226. [CrossRef]

59. Li, W.; Tang, Y.; Deng, X.; Yu, X. Geochemistry of the Trace Elements in the High Organic Sulfur Coals from Chenxi Coalfield. J. China Coal Soc. 2013, 38, 1227-1233.

60. Liu, G.; Yang, P.; Peng, Z.; Wang, G.; Zhang, W. Comparative Study of the Quality of Some Coals from the Zibo Coal Field. Energy 2003, 28, 969-978. [CrossRef]

61. Cui, G.; Quan, S.; Wu, C. Jurassic Coal in Yanqi Basin (Xinjiang, China): Geochemical Characteristics of Trace Elements and Their Implications. Acta Sci. Nat. Univ. Pekin. 2004, 40, 594-600, (In Chinese with an English Abstract).

62. Zheng, L.; Liu, G.; Chou, C.; Gao, L.; Peng, Z. Arsenic in Chinese Coals: Its Abundance, Distribution, Modes of Occurrence, Enrichment Processes, and Environmental Significance. Acta Geosci. Sin. 2006, 27, 355-366, (In Chinese with English abstract).

63. Reimann, C.; De Caritat, P. Chemical Elements in the Environment: Factsheets for the Geochemist and Environmental Scientist; Springer Science \& Business Media: New York, NY, USA, 2012; p. 397.

64. Shao, L.; Jones, T.; Gayer, R.; Dai, S.; Li, S.; Jiang, Y.; Zhang, P. Petrology and Geochemistry of the High-Sulphur Coals from the Upper Permian Carbonate Coal Measures in the Heshan Coalfield, Southern China. Int. J. Coal Geol. 2003, 55, 1-26. [CrossRef]

65. Dai, S.; Zhang, W.; Seredin, V.V.; Ward, C.R.; Hower, J.C.; Song, W.; Wang, X.; Li, X.; Zhao, L.; Kang, H.; et al. Factors Controlling Geochemical and Mineralogical Compositions of Coals Preserved Within Marine Carbonate Successions: A Case Study from the Heshan Coalfield, Southern China. Int. J. Coal Geol. 2013, 109, 77-100. [CrossRef]

66. Zhao, S. Reductivity of Humic Coal in China and Its Relation to Sedimentary Environment. Acta Sedimentol. Sin. 1984, 2, 53-65.

67. Spiker, E.C.; Pierce, B.S.; Bates, A.L.; Stanton, R.W. Isotopic Evidence for the Source of Sulfur in the Upper Freeport Coal Bed (West-Central Pennsylvania, U.S.A.). Chem. Geol. 1994, 114, 115-130. [CrossRef]

68. Kang, X.; Yang, Q.; Zhang, R.; Zhou, C.; Tang, D.; Liu, D. Occurrence State and Origin of Organic Sulfur in Late Paleozoic Coal, North China. Earth Sci. 1999, 24, 413-417.

69. Casagrande, D.J. Sulphur in peat and coal. In Coal and Coal-Bearing Strata: Recent Advances; Scott, A.C., Ed.; Geological Society Special Publications: London, UK, 1987; Volume 32, pp. 87-105.

70. Westgate, L.M.; Anderson, T.F. Isotopic Evidence for the Origin of Sulfur in the Herrin (no. 6) Coal Member of Illinois. Int. J. Coal Geol. 1984, 4, 1-20. [CrossRef]

71. Smith, J.W.; Batts, B.D. The Distribution and Isotopic Composition of Sulfur in Coal. Geochim. Cosmochim. Acta 1974, 38, 121-133. [CrossRef]

72. Shimoyama, T.; Yamazaki, K.; Iijima, A. Sulphur Isotopic Composition in the Palaeogene Coal of Japan. Int. J. Coal Geol. 1990, 15, 191-217. [CrossRef]

73. Price, F.T.; Shieh, Y. The Distribution and Isotopic Composition of Sulfur in Coals from the Illinois Basin. Econ. Geol. 1979, 74, 1445-1461. [CrossRef]

74. Jiang, Y.; Elswick, E.R.; Mastalerz, M. Progression in Sulfur Isotopic Compositions from Coal to Fly Ash: Examples from Single-Source Combustion in Indiana. Int. J. Coal Geol. 2008, 73, 273-284. [CrossRef]

75. Hunt, J.; Smith, J. ${ }^{34} \mathrm{~S} /{ }^{32} \mathrm{~S}$ Ratios of Low Sulfur Permian Australian Coals in Relation to Depositional Environments. Chem. Geol. 1985, 58, 137-144. [CrossRef] 
76. Dai, S.; Ren, D.; Tang, Y.; Shao, L.; Li, S. Distribution, Isotopic Variation and Origin of Sulfur in Coals in the Wuda Coalfield, Inner Mongolia, China. Int. J. Coal Geol. 2002, 51, 237-250. [CrossRef]

77. Lei, J. Sulfur-accumulating Model of Superhigh Organosulfur Coal from Guiding. China. Chin. Sci. Bull. 1994, 39, 1817-1821.

78. Chou, C.L. Sulfur in coals: A Review of Geochemistry and Origins. Int. J. Coal Geol. 2012, 100, 1-13. [CrossRef]

79. Williams, E.; Keith, M. Relationship between Sulfur in Coals and the Occurrence of Marine Roof Beds. Int. J. Coal Geol. 1963, 58, 720-729. [CrossRef]

80. Dai, S.; Ren, D.; Zhou, Y.; Chou, C.L.; Wang, X.; Zhao, L.; Zhu, X. Mineralogy and Geochemistry of a Superhigh-Organic-Sulfur Coal, Yanshan Coalfield, Yunnan, China: Evidence for a Volcanic Ash Component and Influence By Submarine Exhalation. Chem. Geol. 2008, 255, 182-194. [CrossRef]

81. Gayer, R.A.; Rose, M.; Dehmer, J.; Shao, L.Y. Impact of Sulphur and Trace Element Geochemistry on the Utilization of a Marine-Influenced Coal—Case Study from the South Wales Variscan Foreland Basin. Int. J. Coal Geol. 1999, 40, 151-174. [CrossRef]

82. Casagrande, D.J.; Siefert, K.; Berschinski, C.; Sutton, N. Sulfur in Peat-Forming Systems of the Okefenokee Swamp and Florida Everglades: Origins of Sulfur in Coal. Geochim. Cosmochim. Acta 1977, 41, 161-167. [CrossRef]

83. Chou, C.L. Geochemistry of Sulfur in Coal. In Geochemistry of Sulphur in Fossil Fuels; Orr, W.L., White, C.M., Eds.; American Chemical Society Symposium Series: Washington, DC, USA, 1990; pp. 30-52.

84. Johnson, C.L.; Greene, T.J.; Zinniker, D.A.; Moldowan, J.M.; Hendrix, M.S.; Carroll, A.R. Geochemical Characteristics and Correlation of Oil and Nonmarine Source Rocks from Mongolia. AAPG Bull. 2003, 87, 817-846. [CrossRef]

85. Bouška, V.; Pešek, J.; Žák, K. Values of $\delta^{34} \mathrm{~S}$ in Iron Disulphides of the North Bohemian Lignite Basin, Czech Republic. In European Coal Geology and Technology; Geological Society Special Publications: London, UK, 1997; Volume 125, pp. 261-267.

86. Widodo, S.; Oschmann, W.; Bechtel, A.; Sachsenhofer, R.F.; Anggayana, K.; Puettmann, W. Distribution of Sulfur and Pyrite in Coal Seams From Kutai Basin (East Kalimantan, Indonesia): Implications for Paleoenvironmental Conditions. Int. J. Coal Geol. 2010, 81, 151-162. [CrossRef]

87. Querol, X.; Cabrera, L.; Pickel, W.; López-Soler, A.; Hagemann, H.W.; Fernández-Turiel, J.L. Geological Controls on the Coal Quality of the Mequinenza Subbituminous Coal Deposit, Northeast Spain. Int. J. Coal Geol. 1996, 29, 67-91. [CrossRef]

88. Bechtel, A.; Reischenbacher, D.; Sachsenhofer, R.F.; Gratzer, R.; Lücke, A.; Püttmann, W. Relations of Petrographical and Geochemical Parameters in the Middle Miocene Lavanttal Lignite (Austria). Int. J. Coal Geol. 2007, 70, 325-349. [CrossRef]

89. Markic, M.; Sachsenhofer, R.F. Petrographic Composition and Depositional Environments of the Pliocene Velenje Lignite Seam (Slovenia). Int. J. Coal Geol. 1997, 33, 229-254. [CrossRef]

90. Siavalas, G.; Linou, M.; Chatziapostolou, A.; Kalaitzidis, S.; Papaefthymiou, H.; Christanis, K. Palaeoenvironment of Seam I in the Marathousa Lignite Mine, Megalopolis Basin (Southern Greece). Int. J. Coal Geol. 2009, 78, $233-248$. [CrossRef]

91. Diehl, S.F.; Goldhaber, M.B.; Koenig, A.E.; Lowers, H.A.; Ruppert, L.F. Distribution of Arsenic, Selenium, and Other Trace Elements in High Pyrite Appalachian Coals: Evidence for Multiple Episodes of Pyrite Formation. Int. J. Coal Geol. 2012, 94, 238-249. [CrossRef]

92. Querol, X.; Whateley, M.K.G.; Fernández-Turiel, J.L.; Tuncali, E. Geological Controls on the Mineralogy and Geochemistry of the Beypazari Lignite, Central Anatolia, Turkey. Int. J. Coal Geol. 1997, 33, 255-271. [CrossRef]

93. Wang, F.; Zhou, X.-H.; Zhang, L.-C.; Ying, J.-F.; Zhang, Y.-T.; Wu, F.-Y.; Zhu, R.-X. Late Mesozoic Volcanism in the Great Xing'an Range (NE China): Timing and Implications for the Dynamic Setting of NE Asia. Earth Planet. Sci. Lett. 2006, 251, 179-198. [CrossRef]

94. Guo, F.; Fan, W.; Wang, Y.; Lin, G. Petrogenesis of the Late Mesozoic Bimodal Volcanic Rocks in the Southern Da Hinggan Mts, China. Acta Petrol. Sin. 2001, 17, 161-168, (In Chinese with English Abstract).

95. Stach, E. Stach's Textbook of Coal Petrology; Gebruder Borntraeger: Berlin, Germany, 1982.

96. Lyons, P.C.; Whelan, J.F.; Dulong, F.T. Marine Origin of Pyritic Sulfur in the Lower Bakerstown Coal Bed, Castleman Coal Field, Maryland (U.S.A.). Int. J. Coal Geol. 1989, 12, 329-348. [CrossRef] 
97. Yan, W.; Fan, T.; Wang, H.; Sun, Y.; Yang, F.; Wei, Y.; Hu, X. On the Microfossile Assemblages, Paleoclimate Indicator and Oil-Controlling Significance from the Lower Cretaceous Strata in the Lishu Depression, Songliao Basin, Ne China. Acta Micropalaeontol. Sin. 2014, 31, 175-189, (In Chinese with English Abstract).

98. Tian, M.; Zhang, M.; Ren, Y.; Qiao, X.; Wan, C.; Liu, P. On The Sporopollen Alga Assemblages and Enviroments from the Third Member of Nanjing Formation in the Xinzhan Area of Songliao Basin. J. Jilin Univ. 2005, 35, 449-455, (In Chinese with English Abstract).

99. Sha, J. Cretaceous Stratigraphy of Northeast China: Non-marine and Marine Correlation. Cretac. Res. 2007, 28, 146-170. [CrossRef]

100. Wang, P.; Du, X.; Wang, D. Geochemical Records of the Cretaceous Lacustrine Transgressive sequences and the Marine-lake Connecting Events in the Songliao Basin, Northeast China. Sediment. Facies Paleogeogr. 1995, 15, 14-20, (In Chinese with English Abstract).

101. Casagrande, D.; Siefert, K. Origins of Sulfur in Coal: Importance of the Ester Sulfate Content of Peat. Science 1977, 195, 675-676. [CrossRef] [PubMed]

102. Dai, S. The Action and Significance of Low Organism in the Formation of High-Sulfur Coal. Sci. Geol. Sin. 2000, 9, 339-352.

103. Eldrett, J.S.; Greenwood, D.R.; Harding, I.C.; Huber, M. Increased Seasonality through the Eocene to Oligocene Transition in Northern High Latitudes. Nature 2009, 459, 969-974. [CrossRef] [PubMed]

104. Chen, Z.; Wang, Z.; Schneiderman, J.; Taol, J.; Cail, Y. Holocene Climate Fluctuations in the Yangtze Delta of Eastern China and the Neolithic Response. Holocene 2005, 15, 915-924. [CrossRef]

105. Bartlein, P.J.; Harrison, S.P.; Brewer, S.; Connor, S.; Davis, B.A.S.; Gajewski, K.; Guiot, J.; Harrison-Prentice, T.I.; Henderson, A.; Peyron, O.; et al. Pollen-Based Continental Climate Reconstructions at 6 and $21 \mathrm{Ka:}$ A Global Synthesis. Clim. Dyn. 2011, 37, 775-802. [CrossRef]

106. Akyuz, I.; Warny, S.; Famubode, O.; Bhattacharya, J.P. Palynology of the Upper Cretaceous (Turonian) Ferron Sandstone Member, Utah, Usa: Identification of Marine Flooding Surfaces and Milankovitch Cycles in Subtropical, Ever-Wet, Paralic to Non-Marine Palaeoenvironments. Palynology 2016, 40, 122-136. [CrossRef]

107. Yang, X.; Li, W.; Batten, D.J. Biostratigraphic and Palaeoenvironmental Implications of an Early Cretaceous Miospore Assemblage from the Muling Formation, Jixi Basin, Northeast China. Cretac. Res. 2007, 28, 339-347. [CrossRef]

108. Lipp, J.; Trimborn, P.; Fritz, P.; Moser, H.; Becker, B.; Frenzel, B. Stable Isotopes in Tree Ring Cellulose and Climatic Change. Tellus B 1991, 43, 322-330. [CrossRef]

109. Libby, L.M.; Pandolfi, L.J.; Payton, P.H.; Marshall, J.; Becker, B.; Giertz-Sienbenlist, V. Isotopic Tree Thermometers. Nature 1976, 261, 284-288. [CrossRef]

110. Pearman, G.; Francey, R.; Fraser, P. Climatic Implications of Stable Carbon Isotopes in Tree Rings. Nature 1976, 260, 771-773. [CrossRef]

111. Wilson, A.; Grinsted, M. 12c/13c in Cellulose and Lignin as Palaeothermometers. Nature 1977, 265, $133-135$. [CrossRef]

112. Widodo, S.; Bechtel, A.; Anggayana, K.; Püttmann, W. Reconstruction of Floral Changes during Deposition of the Miocene Embalut Coal From Kutai Basin, Mahakam Delta, East Kalimantan, Indonesia by Use of Aromatic Hydrocarbon Composition and Stable Carbon Isotope Ratios of Organic Matter. Org. Geochem. 2009, 40, 206-218. [CrossRef]

113. Gröcke, D.R.; Hesselbo, S.P.; Jenkyns, H.C. Carbon-isotope Composition of Lower Cretaceous Fossil Wood: Ocean-Atmosphere Chemistry and Relation to Sea-Level Change. Geology 1999, 27, 155-158. [CrossRef]

114. Murray, A.P.; Edwards, D.; Hope, J.M.; Boreham, C.J.; Booth, W.E.; Alexander, R.A.; Summons, R.E. Carbon Isotope Biogeochemistry of Plant Resins and Derived Hydrocarbons. Org. Geochem. 1998, 29, 1199-1214. [CrossRef]

115. Lücke, A.; Helle, G.; Schleser, G.H.; Figueiral, I.; Mosbrugger, V.; Jones, T.P.; Rowe, N.P. Environmental History of the German Lower Rhine Embayment during the Middle Miocene as Reflected by Carbon Isotopes in Brown Coal. Palaeogeogr. Palaeoclimatol. Palaeoecol. 1999, 154, 339-352. [CrossRef]

116. Holdgate, G.; Wallace, M.; O'Connor, M.; Korasidis, V.; Lieven, U. The Origin of Lithotype Cycles in Oligo-Miocene Brown Coals from Australia and Germany. Int. J. Coal Geol. 2016, 166, 47-61. [CrossRef]

(C) 2018 by the authors. Licensee MDPI, Basel, Switzerland. This article is an open access article distributed under the terms and conditions of the Creative Commons Attribution (CC BY) license (http:/ / creativecommons.org/licenses/by/4.0/). 